\title{
Preliminary Report on the First Season of the Konya-Ereğli (Keyar) Survey 2013
}

\section{Çiğdem Maner}

\section{Q OpenEdition \\ 1 Journals}

\section{Electronic version}

URL: http://journals.openedition.org/anatoliaantiqua/338

DOI: 10.4000/anatoliaantiqua.338

\section{Publisher}

IFEA

\section{Printed version}

Date of publication: 1 January 2014

Number of pages: $343-360$

ISBN: 9782362450136

ISSN: 1018-1946

\section{Electronic reference}

Çiğdem Maner, «Preliminary Report on the First Season of the Konya-Ereğli (Keyar) Survey 2013 », Anatolia Antiqua [Online], XXII | 2014, Online since 30 June 2018, connection on 18 December 2020. URL : http://journals.openedition.org/anatoliaantiqua/338 ; DOI : https://doi.org/10.4000/ anatoliaantiqua.338 


\section{ANATOLIA ANTIQUA ESKI ANADOLU}

\section{XXII}

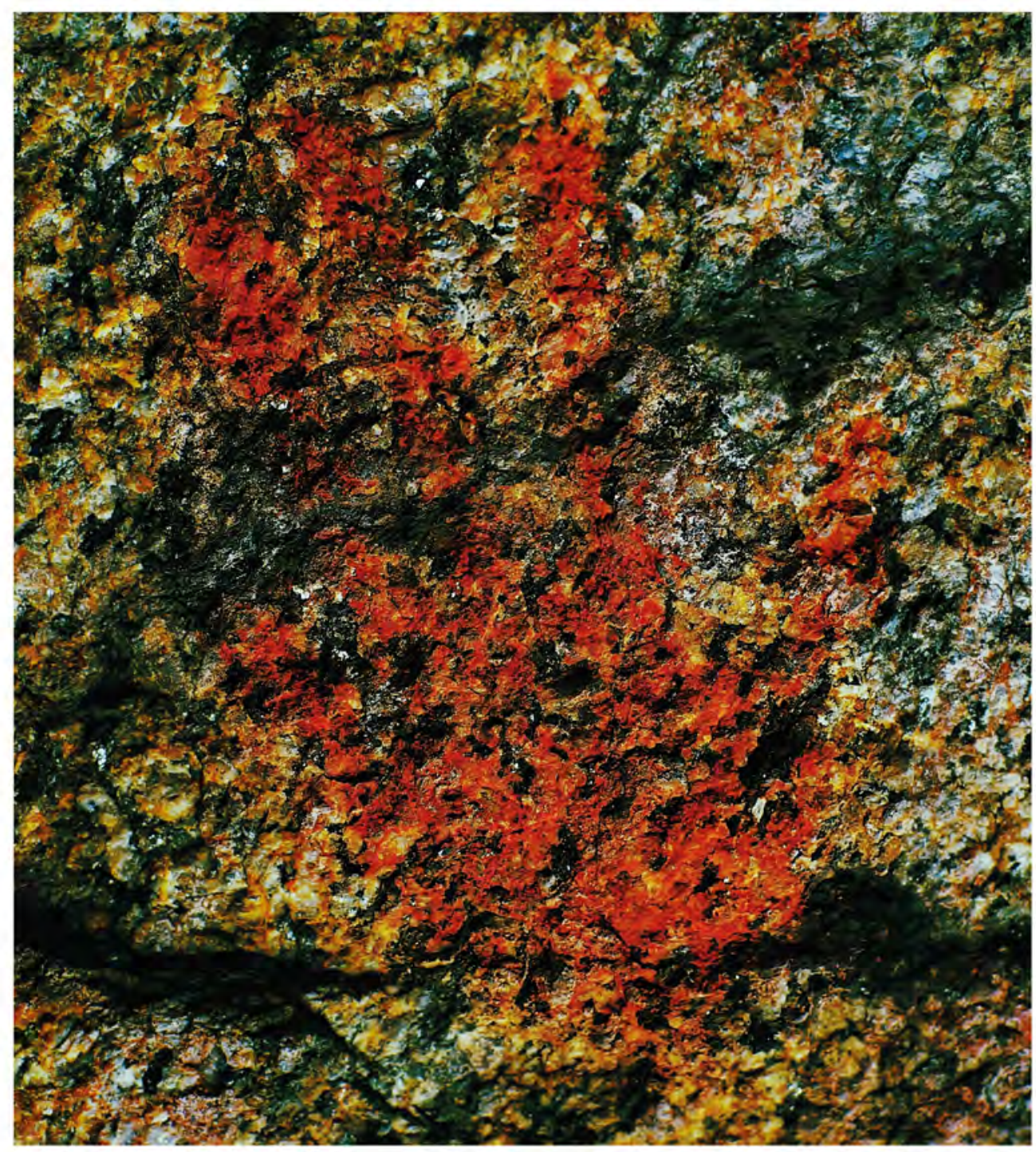

INSTITUT FRANÇAIS D'ETUDES ANATOLIENNES GEORGES-DUMEZIL CNRS USR 3131

DE BOCCARD 


\section{TABLE DES MATIERES}

Emma BAYSAL,

A preliminary typology for beads from the Neolithic and Chalcolithic levels of Barcın Höyük

William ANDERSON, Jessie BIRKETT-REES, Michelle NEGUS CLEARY,

Damjan KRSMANOVIC et Nikoloz TSKVITINIDZE,

Archaeological survey in the South Caucasus (Samtskhe-Javakheti, Georgia):

Approaches, methods and first results

Eda GÜNGÖR ALPER,

Hellenistic and Roman period ceramic finds from the Balatlar Church excavations in

Sinop between 2010-2012

Ergün LAFLI et Gülseren KAN ŞAHİN,

Hellenistic ceramics from Southwestern Paphlagonia

Oğuz TEKIN,

Weights of Lysimachea from the Tekirdağ Museum and various collections

Oğuz TEKIN,

Three weights of Lampsacus

Julie DALAISON et Fabrice DELRIEUX,

La cité de Néapolis-Néoclaudiopolis : histoire et pratiques monétaires

Martine ASSENAT et Antoine PEREZ,

Amida 4. Constance II et Amida

Sencan ALTINOLUK et Nilüfer ATAKAN,

Abrasax: A magical gem in the Istanbul Archaeological Museums

Bahadır DUMAN,

A group of local production Middle Byzantine period pottery from Tripolis:

'Micaceous White Painted Ware'

CHRONIQUES DES TRAVAUX ARCHEOLOGIQUES EN TURQUIE, 2014

Jean-Charles MORETTI,

avec la collaboration de Nicolas BRESCH, Isabel BONORA, Jean-Jacques MALMARY et

Olivier RISS,

Claros, le Temple d'Apollon : travaux réalisés en 2013

Suat ATEŞLIER,

On the excavations of the Zeus Temple of Alabanda 
Olivier HENRY,

avec Ayşe Güliz BİLGIN ALTINÖZ, Jesper BLID, Ömür Dünya ÇAKMAKLI, Andrew DUFTON, Agneta FRECCERO, Linda GOSNER, Ragnar HEDLUND, Pascal LEBOUTEILLER,

Vasilica LUNGU, Felipe ROJAS, Fredrik TOBIN, Baptiste VERGNAUD et

Andrew WATERS,

La mission Labraunda 2013 - Rapport préliminaire

Dominique BEYER, Isabelle CHALIER, Françoise KIRNER,

Françoise LAROCHE-TRAUNECKER et Aksel TIBBET,

Zeyve Höyük - Porsuk. Rapport préliminaire sur la campagne 2013

Çĭ̆dem MANER,

Preliminary report on the first season of the Konya-Ereğli (KEYAR) survey 2013 


\section{Çiğgem MANER*}

\section{PRELIMINARY REPORT ON THE FIRST SEASON OF THE KONYA-EREĞLİ (KEYAR ${ }^{1}$ ) SURVEY 2013}

During the first two weeks of September 2013 a survey was conducted in the southeastern part of Konya. The aim of the ongoing five-year project is to survey the province's towns of Ereğli, Halkapınar, Emirgazi and Karapınar. The survey started with the permission of the Turkish Ministry of Culture and Tourism on August $31^{\text {st }}$ and ended on September $13^{\text {th }}$ $2013^{2}$. The ministry representative was Mrs. Dilek Atalay from the Ereğli Museum. The survey was primarily funded by Koç University ${ }^{3}$. The municipality of Ereğli kindly offered us housing, and Demireller Tesisleri partially sponsored our dinners ${ }^{4}$.

So far this region has not been systematically surveyed. Only a few villages in the region were visited by James Mellaart ${ }^{5}$ and Semih Güneri ${ }^{6}$. The aim of this survey is to investigate the settlements and landscape of the Bronze and Iron Ages, and to evaluate whether there is evidence for connections with the cultures and civilizations of Anatolia and the Mediterranean, Levant, Mesopotamia, Cyprus, Crete and Greece. A second focus of the survey is on interconnections and networks within this region. Where are the borders of cultural interaction zones? Is it possible to determine them? A third focus is on the Hittite and Neo Hittite period in this region.

During the first season, twenty-two villages east, southeast, southwest and west of Ereğli were visited and fourteen ancient settlements were recorded, twelve of which are new discoveries. Three types of settlements could be determined during the first field season: höyüks (mounds), flat settlements and settlements on hills.

\section{GEOGRAPHY}

Ereğli, Halkapınar, Emirgazi and Karapınar are situated north of the Taurus mountain range. All are located at the southern and southeastern edge of the Konya plain. The region surveyed is very fertile, which contributes to the destruction of archaeological settlements due to heavy agricultural activity. Apple, white cherries, corn and sunflower are some of the major income-generating crops in this region.

According to J. Mellaart, the Karadağ, the desert region of Karapinar and the fresh and saltwater lakes divide the Konya basin into three great basins: the Çumra Konya basin, the plain of Karaman, and the ova (valley) between Ereğli and Bor. He states that the most fertile is the Konya basin and that the Ereğli-Bor basin was important for its strategic location due to its proximity to the Cilician Gates and for the silver found in the Bolkar mountain?

\section{EREĞLİ MUSEUM}

The Ereğli Museum was established in 1968 and is responsible for the provincial towns of Ereğli, Halkapınar, Emirgazi and Karapınar. The objects in the museum show a wide range from the Paleolithic period through to Ottoman times. Nonetheless, only

*) Dr. Ç. Maner, Koç University, Department of Archaeology and History of Art, cmaner@ku.edu.tr

1) Konya Ereğli Yüzey Araştırması (Konya Ereğli Survey Project)

2) I would like to thank the Koç University students, who have joined the first season: Gülşah Günata M.A., Muhip Çark1 M.A., Alican Kutlay, Aymesey Albay, Betül Gaye Dinç, Naide Gedikli, Canan Arıkan and Gözde Önder. The map and the pottery drawings have been done by Muhip Çarkı M.A.

3) I would like to thank especially the dean of the College of Social Sciences and Humanities of Koç University Prof. Sami Gülgöz for his endless support.

4) The former mayor of Ereğli Mr. Hüseyin Oprukçu was very generous and helped us in every way. I am very grateful for his help and support.

5) Mellaart 1965.

6) Güneri 1989-91.

7) Mellaart 1963: 207 
a few objects are actually from these four towns. Most of the objects were sent from different museums all over Turkey to fill the showcases when the museum was first opened. Over the years the museum bought small finds, pottery and coins from local dealers and villagers, attesting a wide period of settlement in the region. The museum also has very few Middle and Late Bronze Age Hittite objects, notably a clay spool shaped object with decorations on both sides and the lower part of a Hittite bronze figurine ${ }^{8}$.

\section{HISTORICAL GEOGRAPHY}

Ereğli is equated with Cybistra ${ }^{9}$ and Cybistra with Hittite Hupišna ${ }^{10}$. Hupišna is situated in the Lower Land and was mentioned already by Labarnas, who conquered 'every' area, including Tuwanuwa, Hupišna, Wenassa etc. In the prayers of Muwatalli, Mount Sarlaimmi is associated with Hupišna ${ }^{11}$, both seem to be close to each other ${ }^{12}$. The location of Mount Sarlaimmi is uncertain, however R. Borger suggested an equation with İvriz Dağ and the Bolkar mountain ${ }^{13}$. Hupišna is also mentioned in rituals, prayers, god lists and feast descriptions ${ }^{14}$. J. Mellaart, who surveyed Ereğli Kara Höyük, suggested that this settlement is Hupišna ${ }^{15}$.

Concerning the Iron Age, Luwian incriptions and also Assyrian texts are valuable primary sources for this region. During the $1^{\text {st }}$ Millenium B.C. Hupišna was probably part of Tabal ${ }^{16}$. Hupišna is mentioned as Hubušnu in the annals of Shalmaneser III (836 B.C.), who marched against Puhame in Hubušnu ${ }^{17}$. Also texts of Tiglathpilesar III and Esarhaddon mention Hubušnu ${ }^{18}$.

\section{RESEARCH HISTORY}

Several districts of Konya have been surveyed in the last 60 years ${ }^{19}$, leaving aside however the south-eastern area of Konya. J. Mellaart visited a couple of sites during his survey in southern Turkey, exploring the plain areas around Çumra, Karaman and the region between Ereğli and the Cilician Gates $^{20}$. In the latter he visited sites such as Ciller Höyük, Zincirli Höyük, Kızıl Höyük II, Toprak Tepe and Kara Höyük ${ }^{21}$. He also recognized six sites at Karatepe, Akkuyu, Karapınar I, Karapınar II, Kızak, Tilkili and Maltepe ${ }^{22}$. S. Güneri surveyed the mounds of the $2^{\text {nd }}$ Millenium B.C. in the KaramanEreğli region ${ }^{23}$. He collected pottery from three settlement mounds at Kara Höyük, Zincirli Höyük and Gövezli Höyük ${ }^{24}$. This limited research of the Ereğli region led us to develop a research program that would aim at covering the entire area using a systematic approach, focusing our activity in the areas of Emirgazi, Halkapınar and also Karapınar, a region that has been particularly neglected until now.

\section{METHODOLOGY}

In general we followed the main road axes and surveyed their immediate surrounding. Information was collected from local residents and officials in order to pin point on a map known remains and looted areas.

The region is very fertile and is experiencing heavy agricultural activity, which accelerates the destruction of many ancient settlements. Old testimonies of recorded ancient structures which have disappeared today prove the impact of this local activity. An example is the tumuli mentioned by J. Mellaart around Ereğli Kara Höyük ${ }^{25}$, which are no longer visible. In this specific case, villagers recall the presence of those small mounds that they removed in order to extend their field. It seems that the archaeological material that came out of the tumuli were of some importance as locals mention the discovery of bronze cauldrons, weapons and skeletons

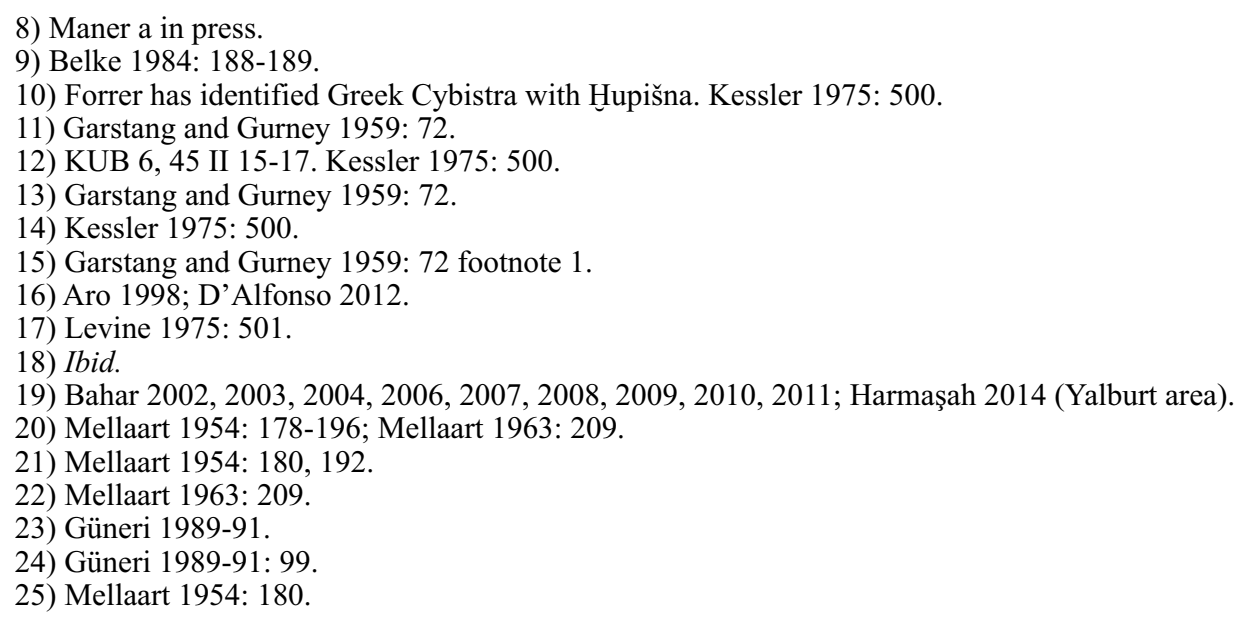




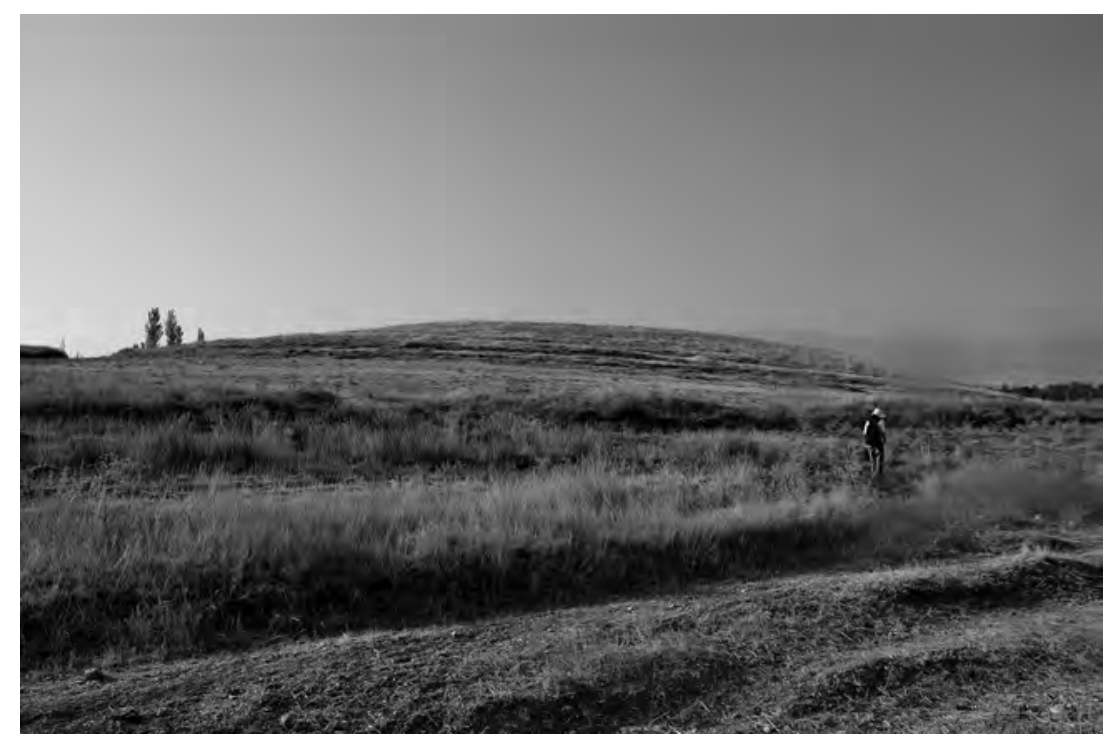

Fig. 1 : Hacımemiş Höyük from the South.

Another blatant example is Değirmentepe in Hacımemiș village, where the owner has removed the top of the mound for agricultural purposes (see below).

On höyüks, which are used for agriculture, the soil is very mixed up or very compacted. In most cases no architectural remains are visible. Hence it is often very difficult to collect an assemblage of pottery. Some höyüks, such as Ereğli Kara Höyük for example, are overgrown with plants, making it impossible to conduct an intensive survey. Under these circumstances the assemblages were collected from larger areas. In most instances pottery and worked stones were collected from pits left over by illegal excavations.

The new regulation enacted by the General Directorate of Antiquities and Museums (paragraph $12 \mathrm{~b}$ of the guideline) forbids the removal of any pottery or small find from sites (besides 'inventory' finds). Hence, we conducted documentation and analysis onsite, limiting the number of sherds that could be recorded as it was not possible to wash and dry the collected material. Only pieces that seemed to be of some significance were therefore systematically photographed and drawn before being returned to their place of origin. Such working conditions make it very difficult to get a clear picture of the regional ceramic faces by creating an assemblage for the region.

\section{KEYAR FIELD SEASON 2013}

In the first season we decided to conduct our investigation first in the district of Ereğli (Map 1). The main reason behind this decision was to complete the survey that had only been partially conducted by both J. Mellaart and S. Güneri. In 2013 the east, southeast, southwest and western part of the province was investigated. In total twenty-two villages were visited: Aziziye, Bulgurluk, Çakmak, Çayhan, Kuskuncuk, Acıpınar, Özgürler, Bahçeli, Beyköy, Hacımemiş, Gökçeyazı, Sarıca, Belceağaç, Orhaniye, Yazlık, Yellice, Ulumeşe, Çimencik, Melicek, Burhaniye, Alhan and Armağanlı.

Fourteen archaeological settlements could be recognized, only two of them (Ereğli Kara Höyük and Toprak Tepe) had been previously known and registered by the authorities. Among the twelve unknown settlements that were documented during our survey are small to large settlement mounds as well as flat settlements.

\section{Hacımemiş Köyü}

Hacımemiş Köyü (village) is situated $3.6 \mathrm{~km}$ east of Ereğli (Map 1). The villagers sustain their income primarily from agriculture, especially from apple and corn. The main road from Ereğli to Hacımemiş leads through the village. There are two settlement mounds in Hacımemiş Köyü, which are separated by this main road, coming from the west. Hacimemis Höyük is situated north of this road while Değirmentepe is to the south. Both sites are currently used for agriculture.

\section{Hacımemiş Höyük}

The mound is of a medium size. It measures $c a$. $260 \mathrm{~m}(\mathrm{~N}-\mathrm{S})$ by $158 \mathrm{~m}(\mathrm{E}-\mathrm{W})$. The settlement seems to cover an area of 4,1 hectares (Map 1, Fig.1 and 2: 1). 


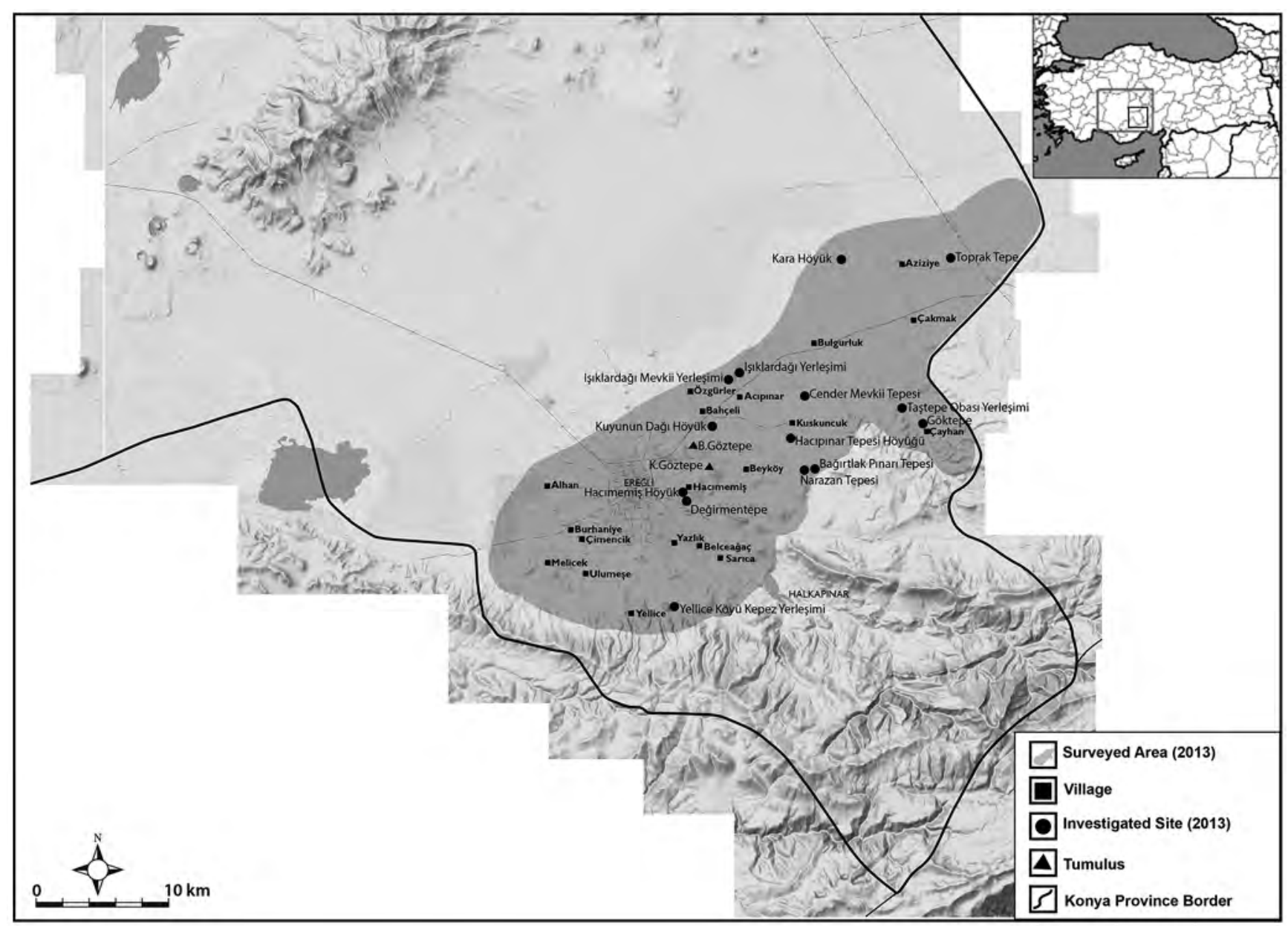

Map 1 : Surveyed area of field season 2013.

Table 1: Investigated Settlements.

\begin{tabular}{|r|l|l|l|}
\hline $\mathbf{N}^{0}$ & Name of Settlement & Village & Altitude \\
\hline $\mathbf{1}$ & Hacımemiş Höyük & Ereğli, Hacımemiş Köyü & $1070.5 \mathrm{~m}$ \\
\hline $\mathbf{2}$ & Değirmentepe & Ereğli, Hacımemiş Köyü & $1068.3 \mathrm{~m}$ \\
\hline $\mathbf{3}$ & Kuyunun Dağı Höyüğü & Ereğli, Kuskuncuk köyü & $1088 \mathrm{~m}$ \\
\hline $\mathbf{4}$ & Acıpınar Tepesi Höyüğü & Ereğli, Kuskuncuk köyü & $1154 \mathrm{~m}$ \\
\hline $\mathbf{5}$ & Cender Mevkii Tepesi & Ereğli, Kuskuncuk köyü & $1116 \mathrm{~m}$ \\
\hline $\mathbf{6}$ & Bağırtlak Pınarı Yerleşimi & Ereğli, Kuskuncuk köyü & $1214 \mathrm{~m}$ \\
\hline $\mathbf{7}$ & Narazan Yerleşimi & Ereğli, Kuskuncuk Köyü & $1213 \mathrm{~m}$ \\
\hline $\mathbf{8}$ & Işılklar Dağı Yerleşimi & $\begin{array}{l}\text { Ereğli, between the villages } \\
\text { of Acrpınar and Bulgurlu }\end{array}$ & $1064 \mathrm{~m}$ \\
\hline $\mathbf{9}$ & Işılar Dağı Mevkii Yerleşimi & $\begin{array}{l}\text { Ereğli, between the villages } \\
\text { of Acrpınar and Bulgurlu }\end{array}$ & $1048 \mathrm{~m}$ \\
\hline $\mathbf{1 0}$ & Kara Höyük & Ereğli, Azziye & $1066 \mathrm{~m}$ \\
\hline $\mathbf{1 1}$ & Toprak Tepe & Ereğli, Aziziye & $1106 \mathrm{~m}$ \\
\hline $\mathbf{1 2}$ & Taştepe Obası Yerleşimí & Ereğli, Taştepe Obası & $1203 \mathrm{~m}$ \\
\hline $\mathbf{1 3}$ & Yellice Köyü Kepez Yerleşimi & Ereğli, Yellice Köyü & $1332 \mathrm{~m}$ \\
\hline $\mathbf{1 4}$ & Göktepe & Ereğli, Cayhan & $1262 \mathrm{~m}$ \\
\hline
\end{tabular}



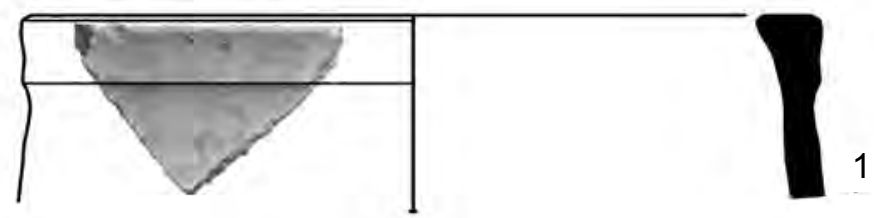

Hacımemiş Höyük
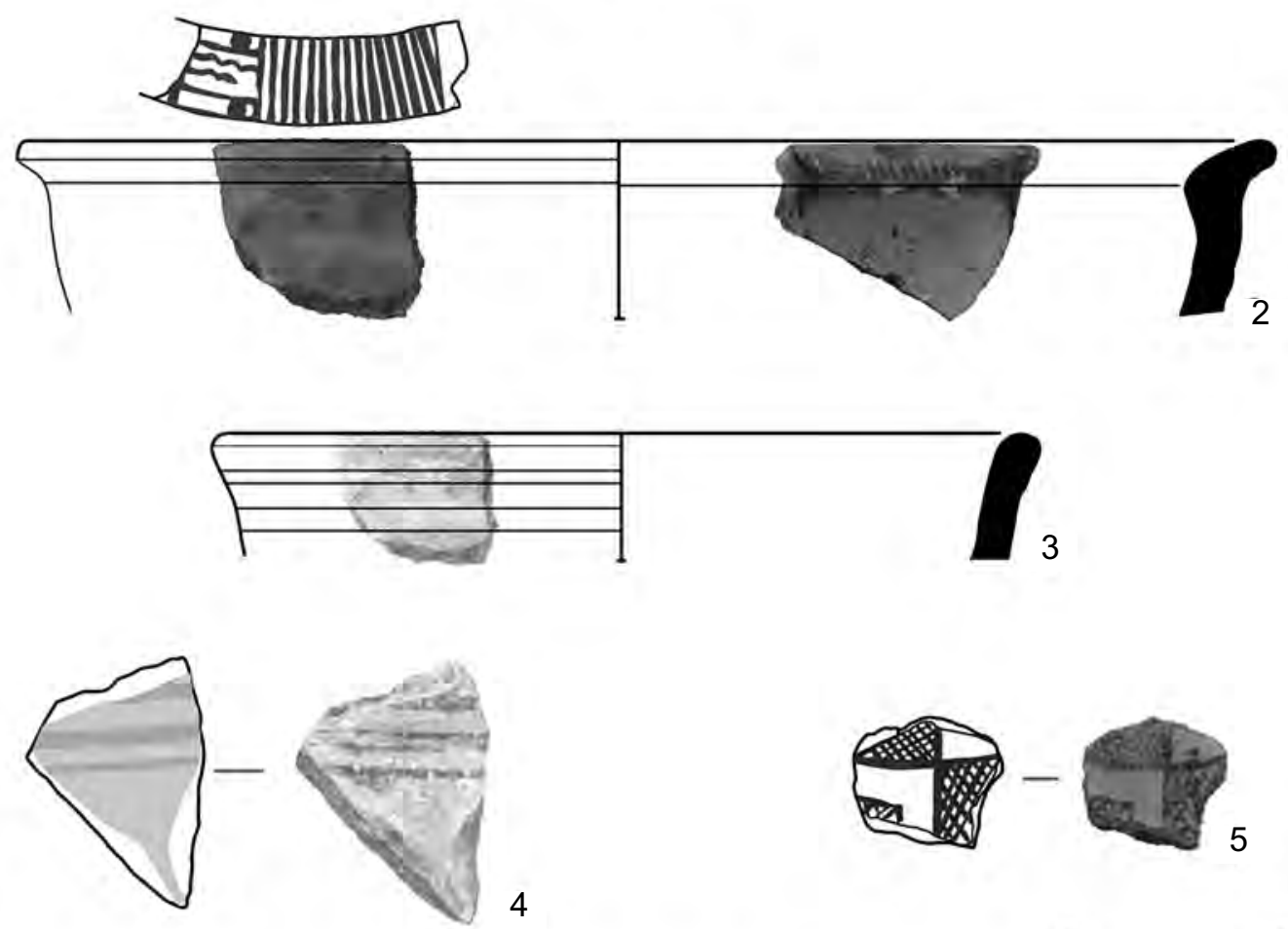

Kuyunun Dağı Höyüğü
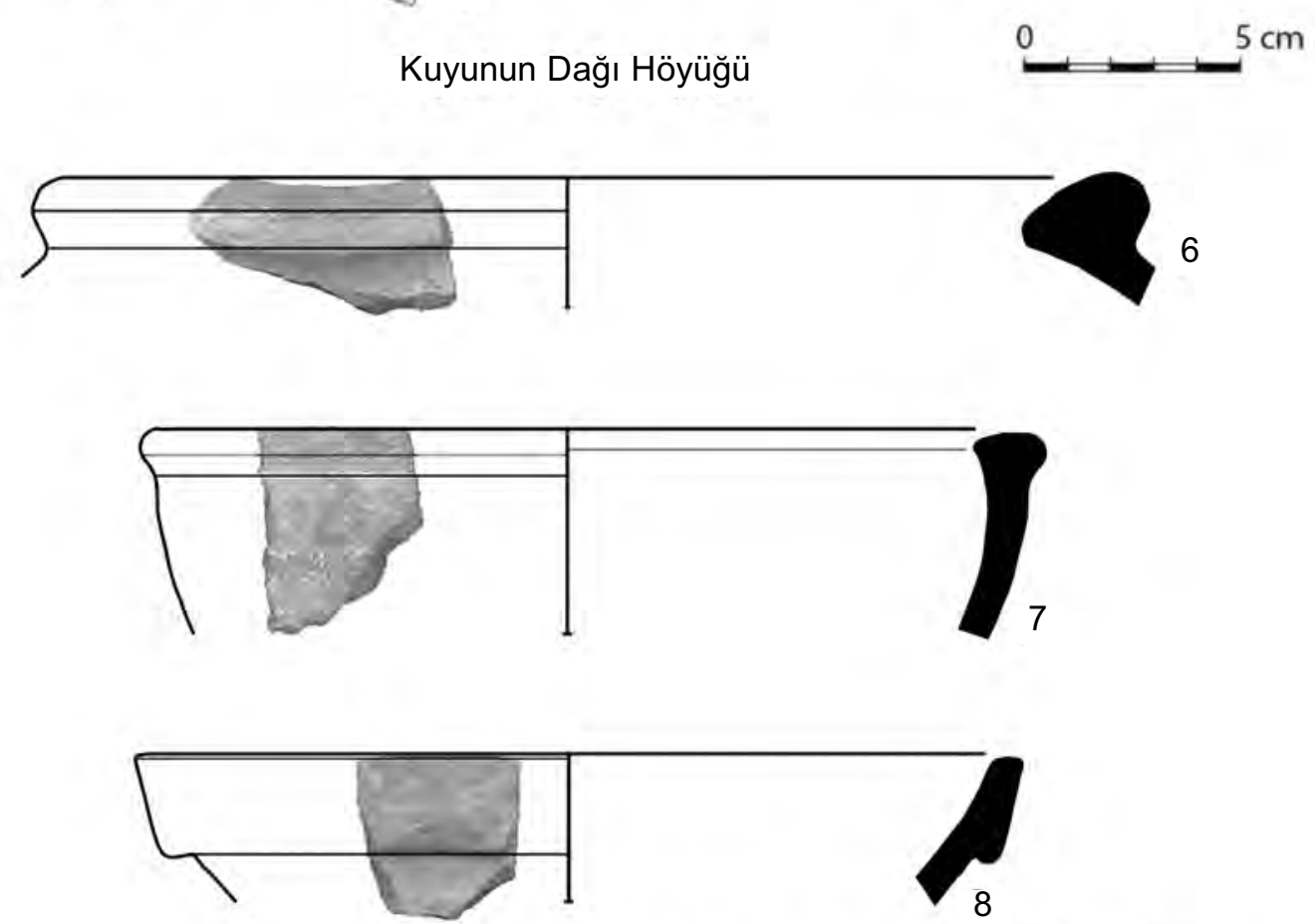

Acıpınar Tepesi Höyüğü 0

Fig. 2 : Selected pottery from Hacımemiş Höyük, Kuyunun Dağı and Acıpınar Tepesi Höyüğü. 

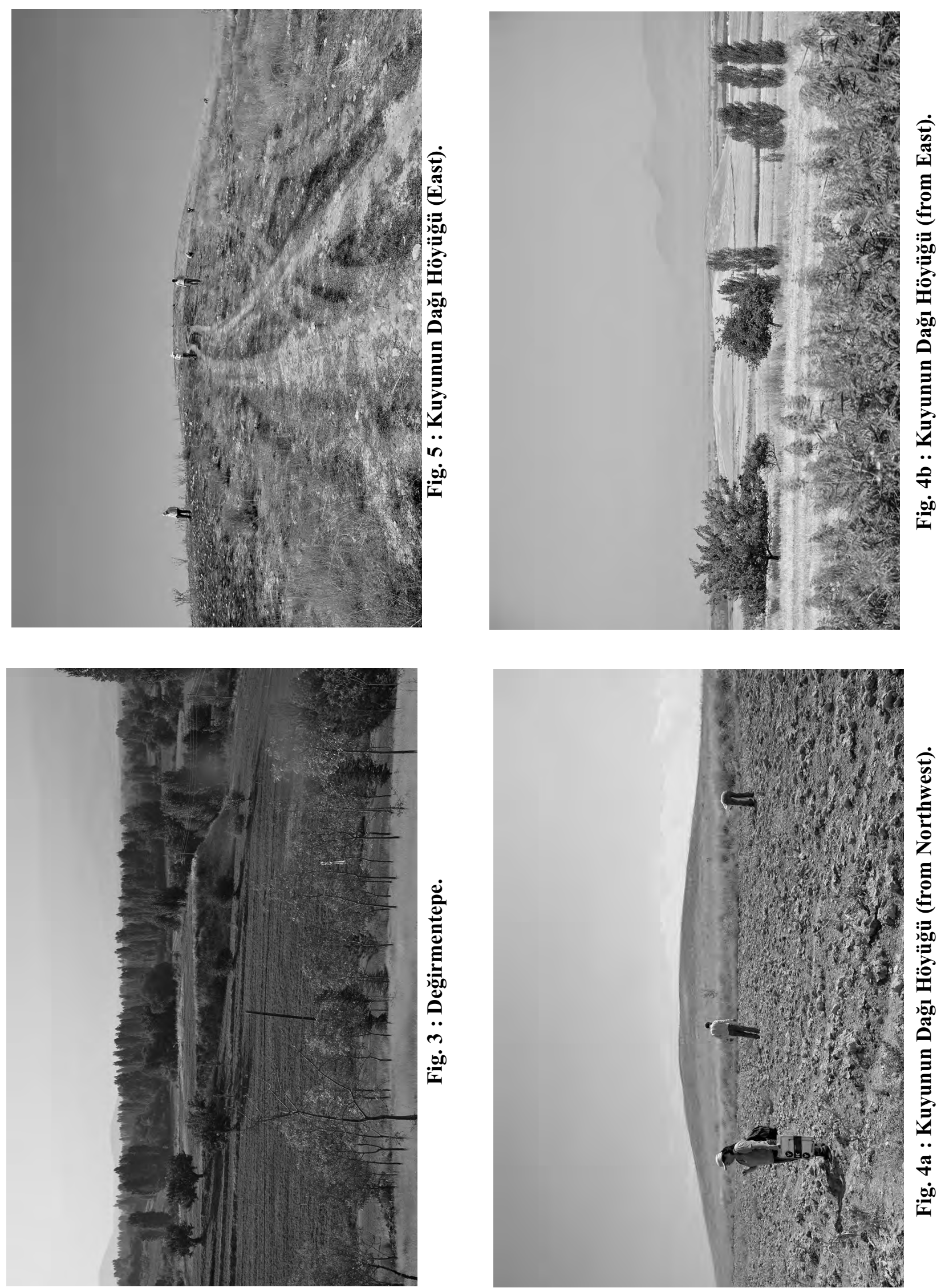

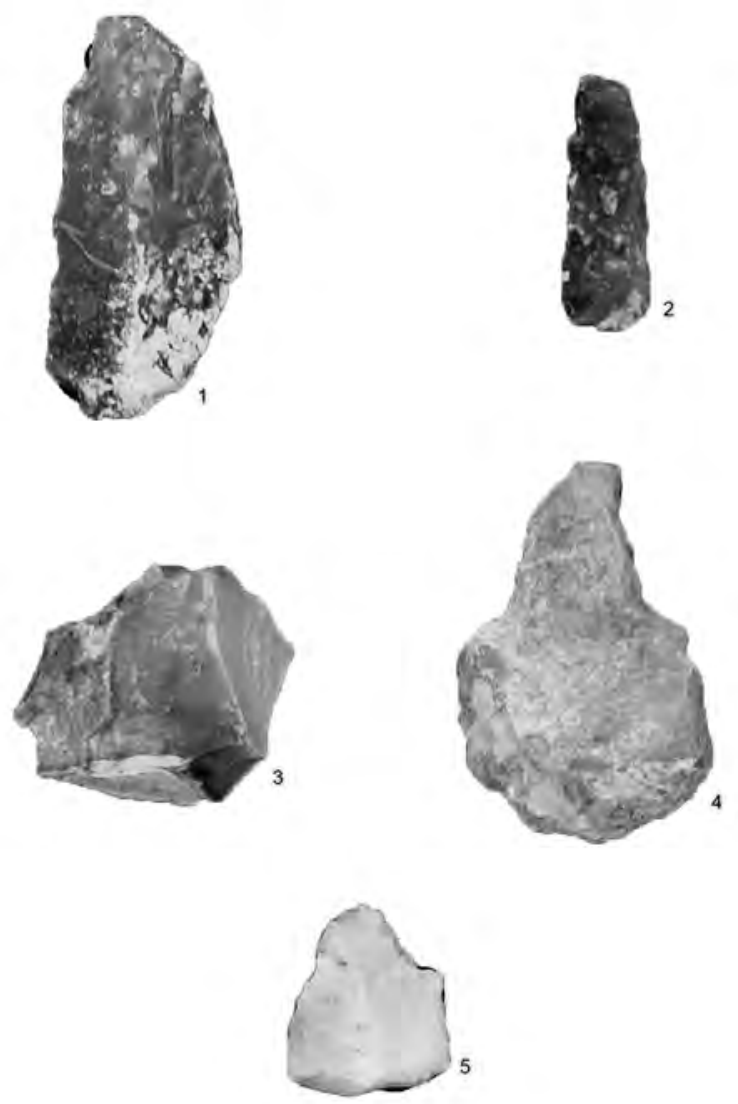

Kuyunun Dağı Höyüğũ

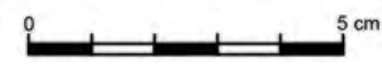

Fig. 6 : Selected stone tools from Kuyunun Dağı Höyüğü.

The mound consists of three artificial terraces, although it is impossible to say whether those are ancient or if they have been built by the villagers. The surface soil is medium-hard and mixed with many mid-size stones. North of the mound are corn fields, while apple trees have been planted in the south. The limited amount of available and collected pottery shows a wide chronological range from Chalcolithic era to the Byzantine period.

\section{Değirmentepe}

Değirmentepe is situated south of Hacımemiş Höyük (Map 1, Fig. 3). Northeast of the mound apple trees have been planted, while one finds sunflowers to the south and wheat, barley and clover to the east. Until 1993 a mill was standing on top of the mound, hence the name Değirmentepe. The top of the mound is at an altitude of $1068.3 \mathrm{~m}$ above sea level (a.s.1.). The mound itself measures $c a .47 \mathrm{~m}(\mathrm{~N}-$

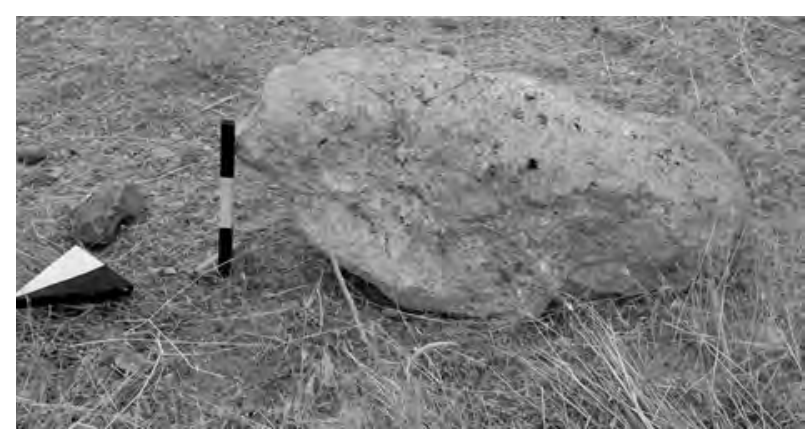

Fig. 7 : Animal sculpture (Kuyunun Dağı Höyüğü).

S) by $64 \mathrm{~m}(\mathrm{E}-\mathrm{W})$, covering a surface $c a .0 .3$ hectares. The owner of this höyük stated that $3 \mathrm{~m}$ of the top-soil were removed to prepare a field for apple trees. While flattening the top, the workers discovered tombs, which they apparently looted. The number of sherds on the surface was limited. Among them were a piece of ancient glass, part of a mudbrick and nine pottery fragments, two of them glazed. These finds date the settlement to a rather later period, probably Middle to Late Byzantine or maybe even Seljuk period.

\section{Kuyunun Dağı Höyüğg̈}

This settlement mound is situated some $2 \mathrm{~km}$ south of Acipinar village and $4.7 \mathrm{~km}$ northwest of Kuskuncuk village (Map 1, Fig. 2, 4-6). The settlement mound is, together with Acipinar Tepesi Höyüğü (see below), one of the largest settlement mounds in this area. Kuyunun Dağ 1 Höyügü is a spoon-shaped settlement and consists of four mounds of different elevations. In front of the northern side a concrete water channel follows the slope of the mound. The mound measures $1300 \mathrm{~m}(\mathrm{NW}-$ SE) by $308 \mathrm{~m}(\mathrm{E}-\mathrm{W})$ and covers an area of $c a .40$ hectares. The northwestern part of the mound is higher than the rest and resembles an acropolis (at $1097 \mathrm{~m}$ a.s.1.). Its slopes are steep, especially on its southeastern side. The top of the acropolis is enclosed by a stone-wall, of which only a little elevation is visible. It is built of mid-size stones and might belong to a fortification wall. On the eastern slope one notices the presence of oblong piles of stones, which could be covering graves.

Pottery was widespread in the field east of the mound and also on the slopes of the acropolis. However, the top of the acropolis is used for agriculture and had been burnt before our arrival, therefore only very few pottery sherds were found and collected. Most of the pottery sherds were collected on the eastern slope. They mainly date from Chalcolithic 


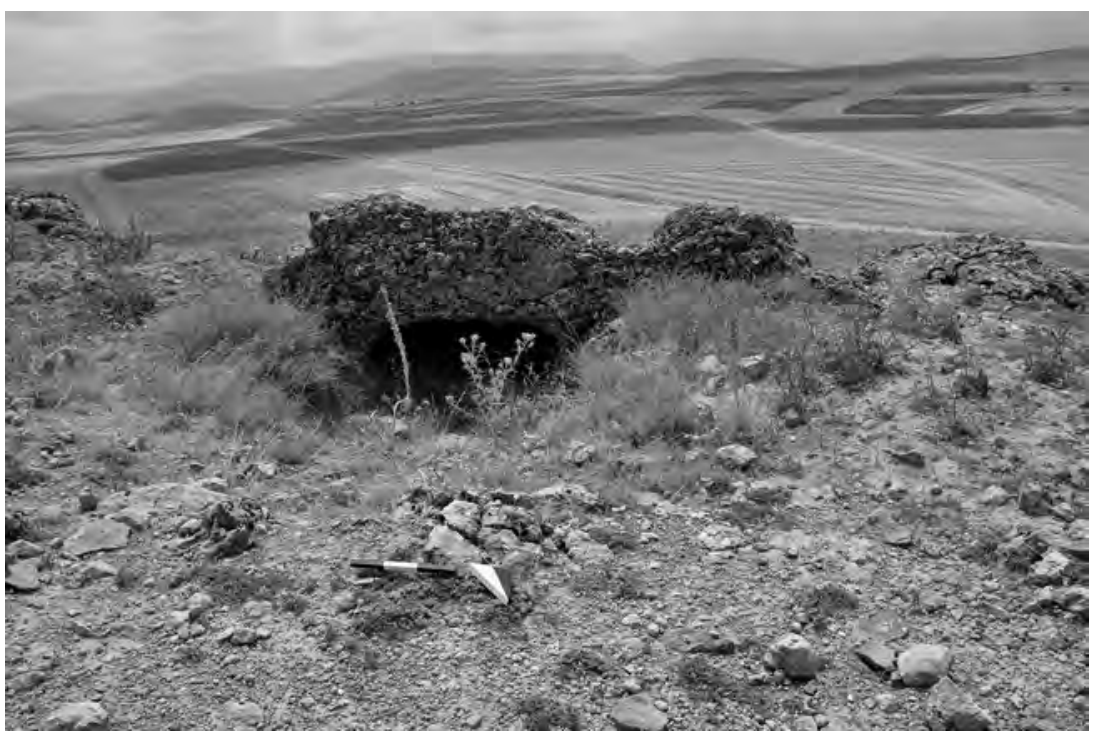

Fig. 8 : Acipınar Tepesi Höyüğü: remains of a stone arch.

Fig. 9a : Acıpınar Tepesi Höyüğü (from West).
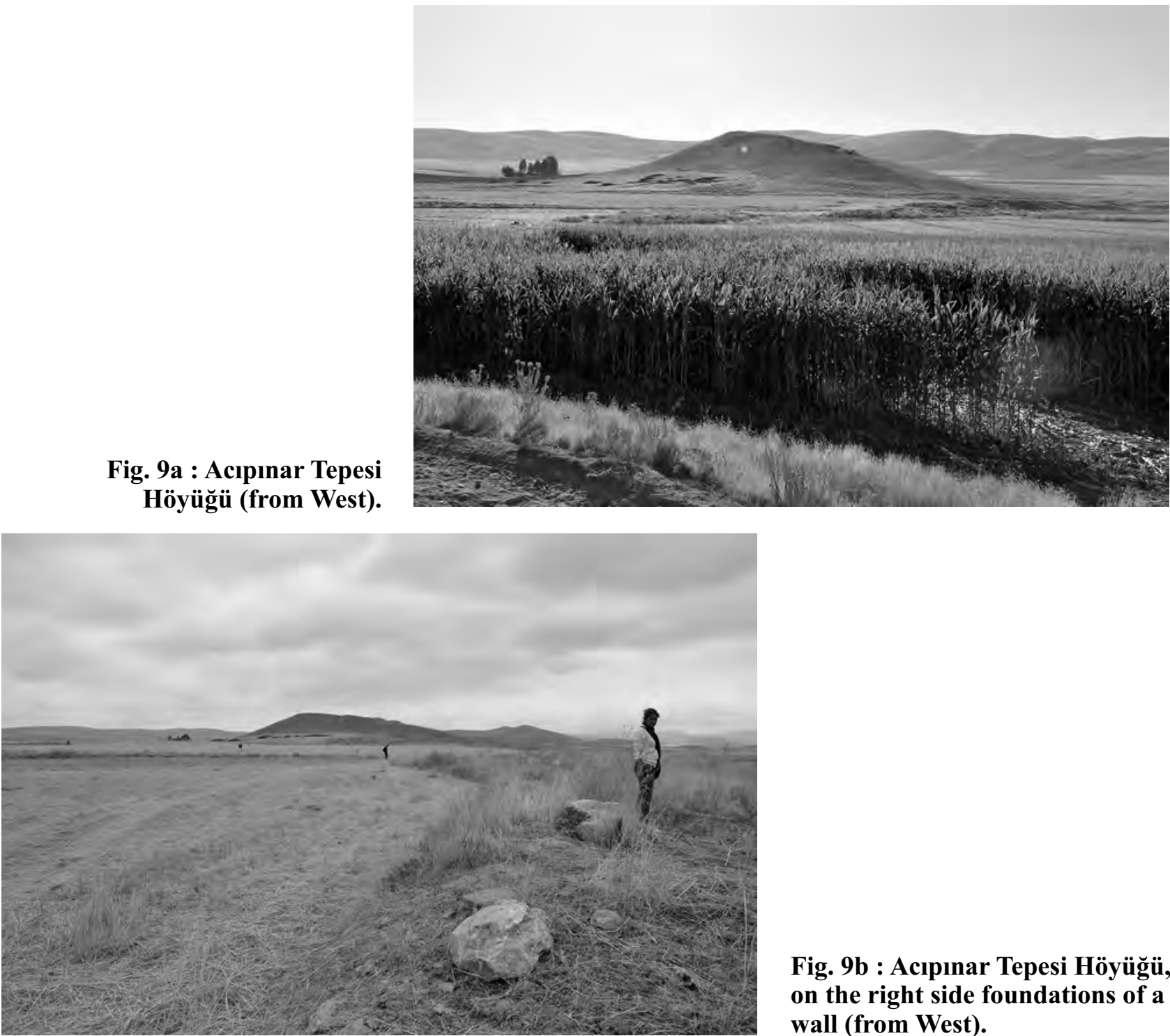

Fig. 9b : Acıpınar Tepesi Höyüğü, on the right side foundations of a wall (from West). 


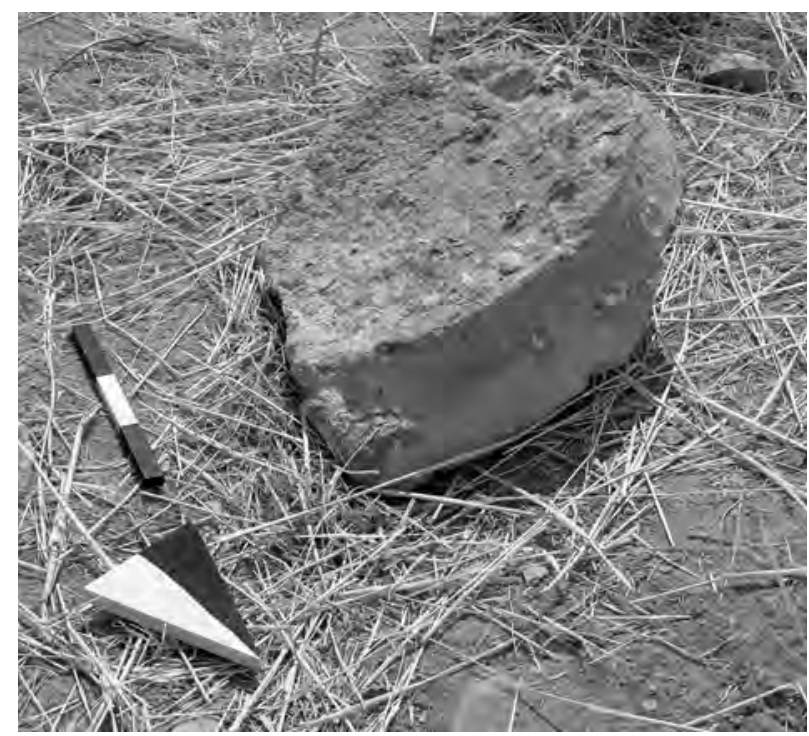

Fig. 10 : Capital in doric order.

era to Roman period. A few important Iron Age fragments were discovered (Fig. 2:2-5). The vessel type, along with the decoration of Fig. 2:2 is known from Porsuk Zeyve Höyük level IV ${ }^{26}$ and seems to become more frequent in level III $^{27}$. This type is also found in the Middle Iron Age levels of Tarsus Gözlükule $^{28}$. On the southern part of the mound the amount of pottery was limited, but a few chipped and worked stones were found (Fig. 7). Part of a sculpture of an animal was found down at the bottom of the western slope (Fig. 8). The back and bottom are hammered, smooth and shiny, while the sides are mainly roughly worked. The head is either damaged or unfinished. The ears are small and round and the nose protrudes. The piece is made of limestone and measures $c a .65 \mathrm{~cm}$ long by $c a .30 \mathrm{~cm}$ wide and $c a$. $40 \mathrm{~cm}$ high. The depicted animal could be a lion or sheep. There are no specific characteristics to date the sculpture.

\section{Acıpınar Tepesi Höyüğ̈̈}

Acıpınar Tepesi Höyüğü is situated $c a .1 \mathrm{~km}$ south of Kuskuncuk village (Map 1, Fig. 8-9). The top of the mound is at an altitude of $c a .1154 \mathrm{~m}$ a.s.l. The höyük covers $c a$. 17 hectares and measures 289 $\mathrm{m}(\mathrm{N}-\mathrm{S})$ by $594 \mathrm{~m}(\mathrm{E}-\mathrm{W})$. The settlement consists of the mound itself and the field west of the mound. The remains of a $c a .1 .5 \mathrm{~m}$ wide stone-wall emerge from the filed. This wall is leading toward the mound and measures $c a .50 \mathrm{~m}$ long. The amount of col-

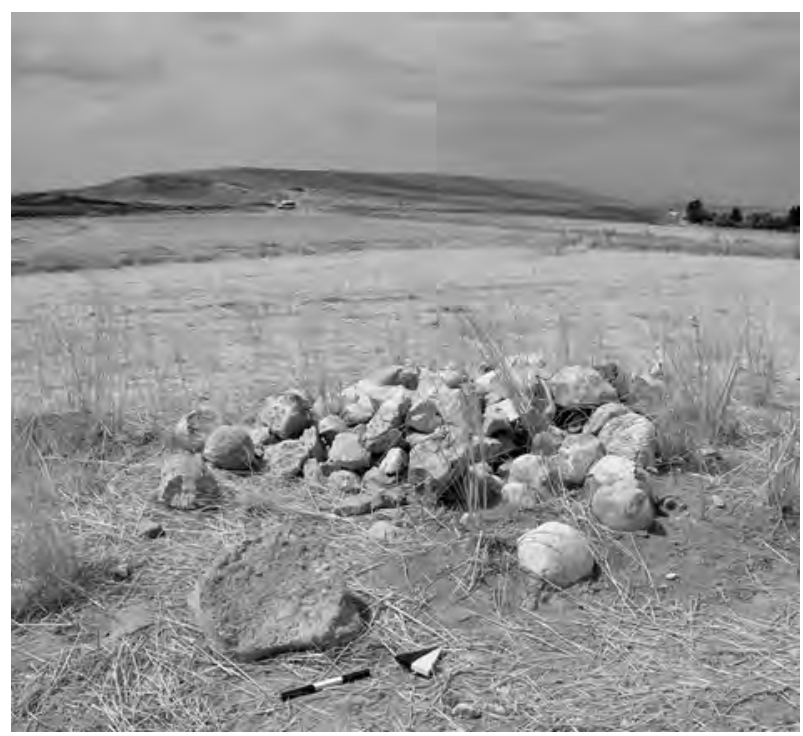

Fig. 11 : Stone pile and doric capital.

lected pottery, including pithos fragments and tiles, was high. Such prolific material might be the result of the apparent intensive illegal excavations that have been conducted both in the field and on the mound, which are also both used for agriculture.

The mound consists of three ancient artificial terraces. On the southern slope one notices a row of leveled rocks, which seem likely to have been used as a base for a wall-foundation. The top of the mound has been largely destroyed by deep illicit excavation pits. On the southern part of the mound top, remains of arches are visible between the rocks and earth rubbles. The only piece of worked stone that was discovered in the field is a partly preserved Doric capital cut in sandstone (Fig.10). It is decorated with two parallel incised horizontal lines. Next to the Doric capital is a pile of fragmented stones (Fig. 11), among which no architectural pieces could be identified. The collected pottery shows a wide chronological range from the Early Bronze Age to the Roman period, including Late Bronze Age and Iron Age sherds (Fig. 2: 6-8). In the field, the collected material is mainly represented by fragments of Roman pithos and roof tiles.

\section{Cender Mevkii Tepesi}

This small settlement lies $2 \mathrm{~km}$ north of Kuskuncuk (Map 1, Fig. 12). The mound measures $55 \mathrm{~m}(\mathrm{~N}-$ S) by $63 \mathrm{~m}$ (W-E) and covers an area of $c a .0 .34$ hectares. The whole mound is used for agriculture. 


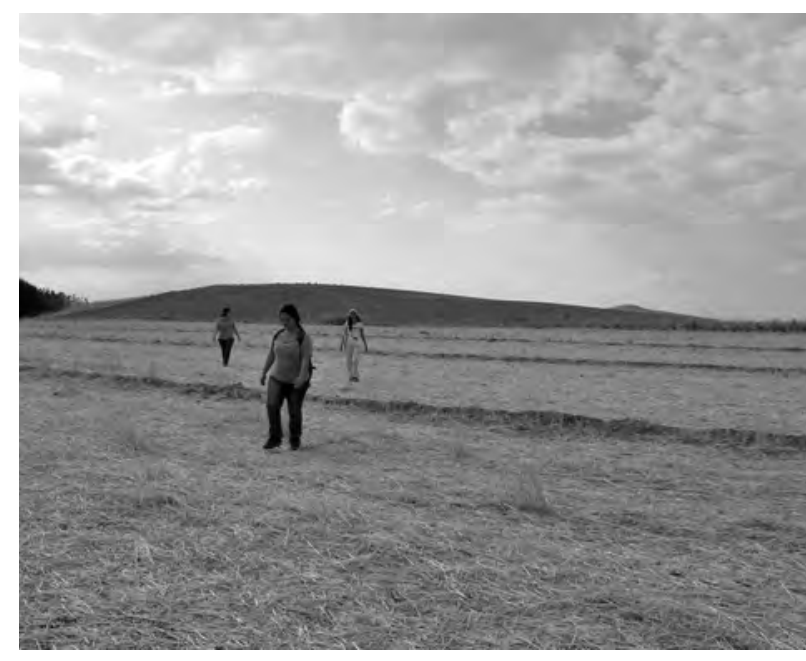

Fig. 12 : Cender Mevkii Tepesi (from East).

Hence the top of the mound has been flattened and is now covered by a heavy layer of pebble stones. No architectural remains are visible. Only a few pottery sherds were found, mainly body sherds, giving a chronological range from the Bronze Age to the Roman period.

\section{Bağırtlak Pınarı Yerleşimi}

This settlement mound is situated $c a .1 .5 \mathrm{~km}$ south of Acıpınar Tepesi (Map 1, Fig. 13), with which it has a clear visual connection, and lies west of Narazan tepesi (see below). It measures $93 \mathrm{~m}(\mathrm{~N}-$ S) by $60 \mathrm{~m}(\mathrm{E}-\mathrm{W})$ and covers an area of $c a .0 .55$ hectares. The site is called Bağırtlak Pınarı by the local villagers because of a small artificial pond. The ancient settlement is placed on a natural hilltop and is used as an agricultural field today. The field shows many illegal diggings, from which a lot of material was collected. The pottery shows a wide chronological range from the Chalcholithic era to the Iron Age (Fig. 14: 9-11).

\section{Narazan Yerleşimi}

This is a natural mound with an altitude of 1213 m a.s.l., situated west of Bağırtlak Pınar Yerleşimi (Map 1). The hill is known by local people as Narazan Tepesi. Only a few pottery pieces, mainly body sherds probably dating to the Early or Middle Bronze Ages, were found on the southeastern slope. Down the southern slope a circular carving in the bedrock, $40 \mathrm{~cm}$ deep and $c a .30 \mathrm{~cm}$ in diameter, was discovered (Fig. 15).

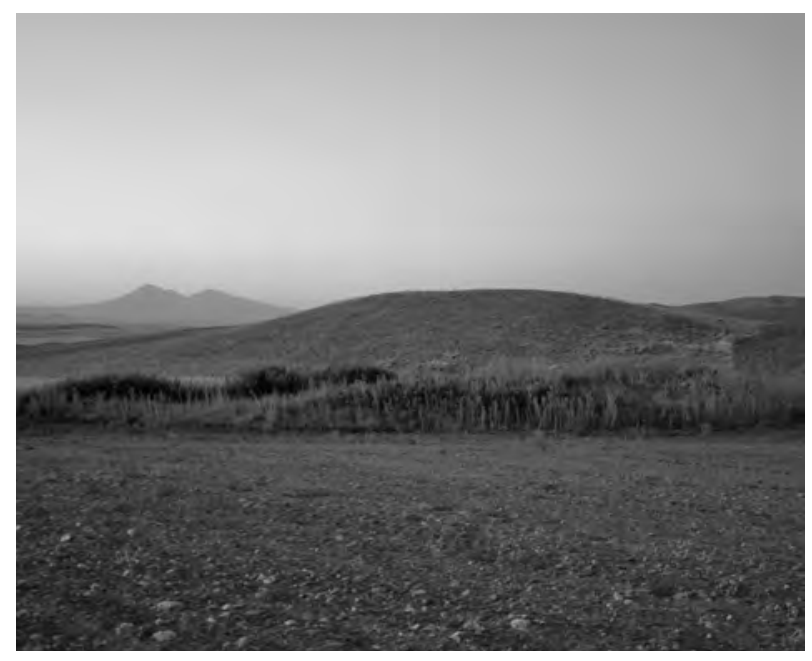

Fig. 13 : Bağırtlak Pınarı Yerleşimi (from South).

\section{Işıılar Dağı Yerleşimi}

This settlement is located $c a .0 .5 \mathrm{~km}$ west of

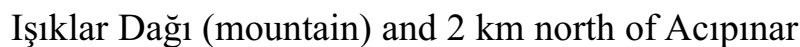
(Map 1, Fig. 16-17). The ancient settlement was discovered within a field. It measures $c a .250 \mathrm{~m}(\mathrm{~N}-\mathrm{S})$ by $142 \mathrm{~m}(\mathrm{E}-\mathrm{W})$ and covers an area of $c a$. 3.5 hectares. This settlement was mentioned by the muhtar of Acipinar, who had found pithoi fragments while plowing. It is a flat settlement, situated on the slope of Iş1klar Dağı. The pottery collected from the field shows a continuous occupation of the area from Bronze Age, to Iron Age, to Hellenistic and Roman periods; notable among them are painted Iron Age sherds (Fig. 14: 12). Many Roman tiles and pithos fragments were observed, though no architecture or worked stones were found.

\section{Işıklar Dağı Mevkii Yerleşimi}

This small settlement is situated on two natural hills, on the southern slope of Işı1klar Dağ,$c a .1 \mathrm{~km}$ southeast of Işıklar Dağ Yerleşimi and $c a .1 .3 \mathrm{~km}$ north of Acipinar (Map 1, Fig. 17). A water canal runs in front of the mound. The settlement measures $72 \mathrm{~m}(\mathrm{~N}-\mathrm{S})$ by $86 \mathrm{~m}(\mathrm{E}-\mathrm{W})$ and is $c a .0 .6$ hectares wide. Aside from the northern part of the mound all other areas are used for agriculture. Pottery was found only on the eastern slope; within this assemblage Late Bronze Age and Middle Iron Age pottery could be identified (Fig. 14: 13). 

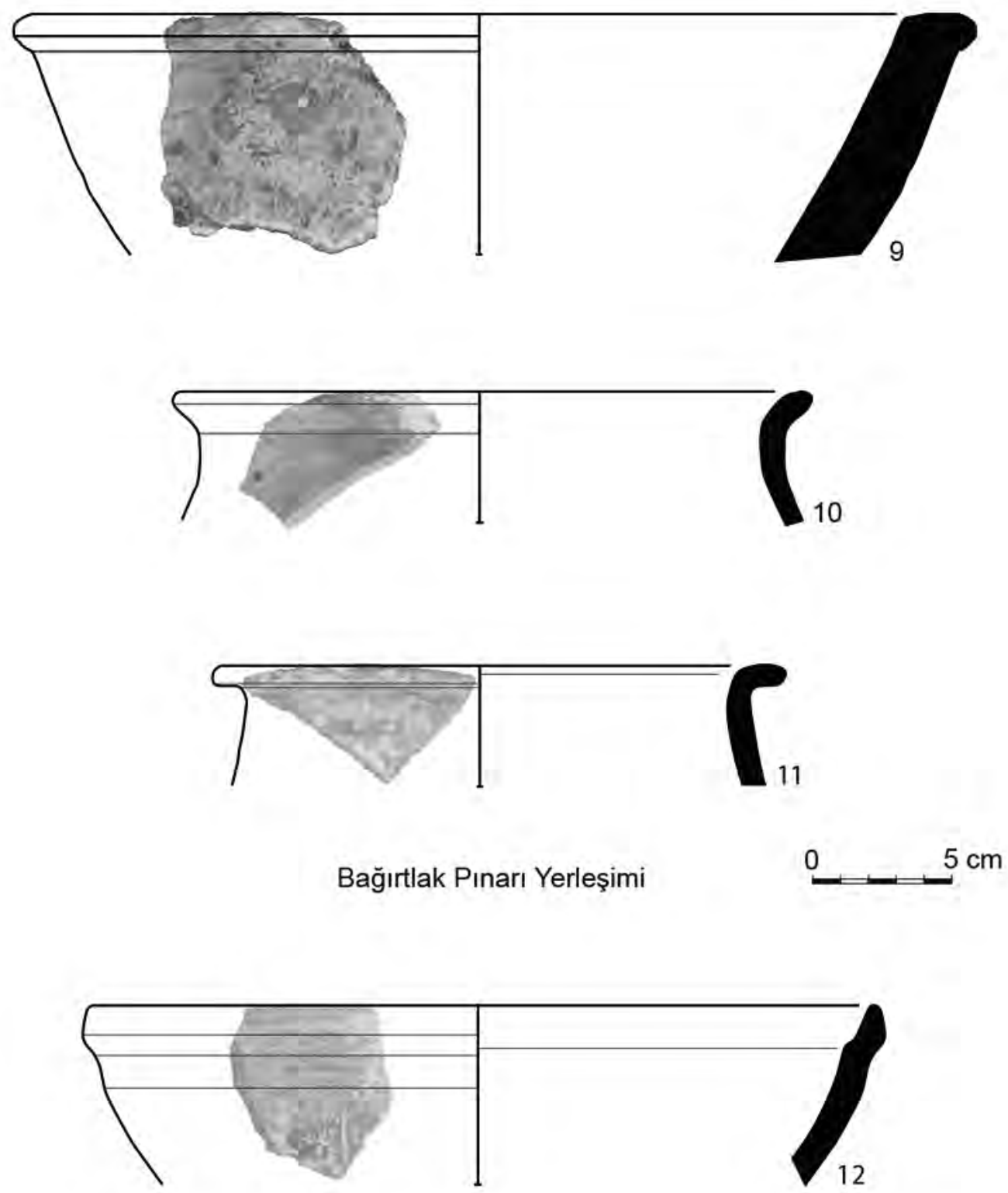

Işıklar Dağı Yerleşimi

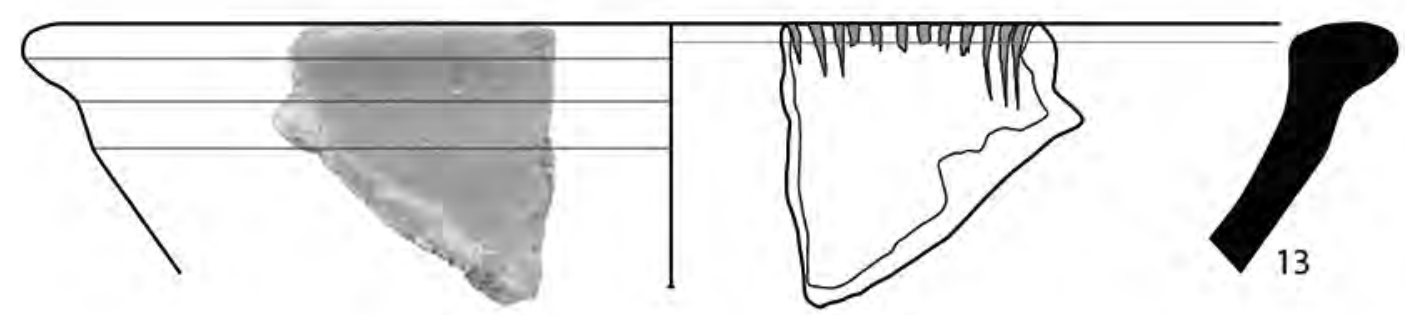

Işıklardağı Mevkii Yerleşimi

0 $5 \mathrm{~cm}$

Fig. 14 : Selected pottery from Bağırtlak Pınarı Yerleşimi, Işıklar Dağı Yerleşimi and Işıklardağı Mevkii Yerleşimi. 


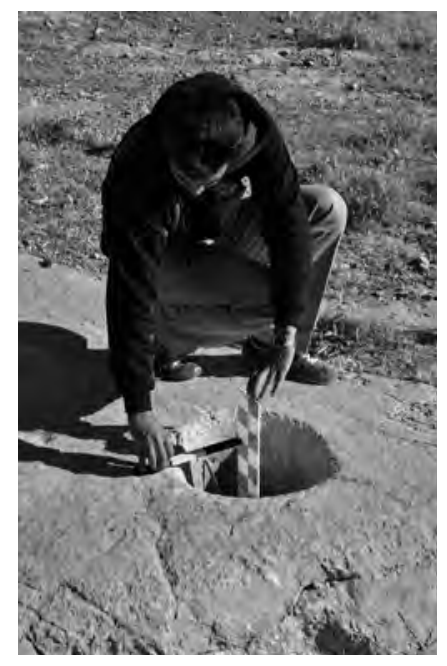

Fig. 15 : Narazan

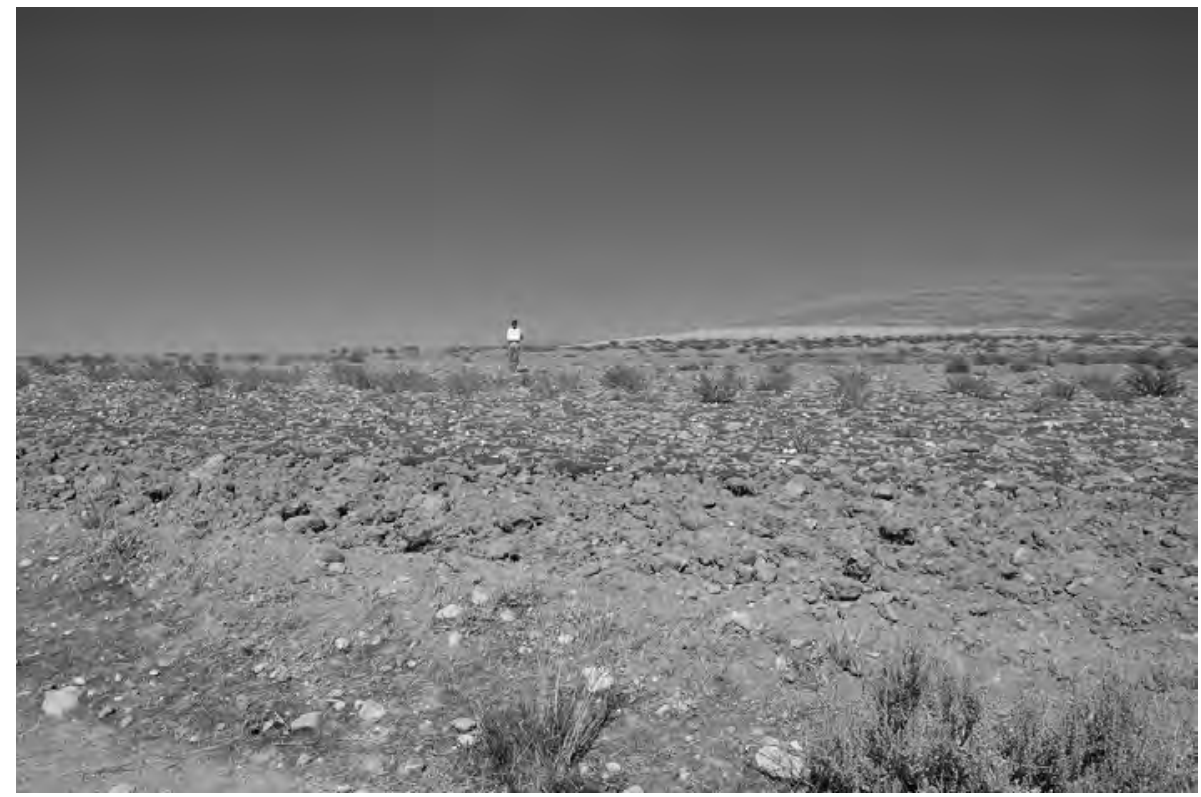

Yerleşimi.

Fig. 16 : Işıklar Dağı Yerleşimi.

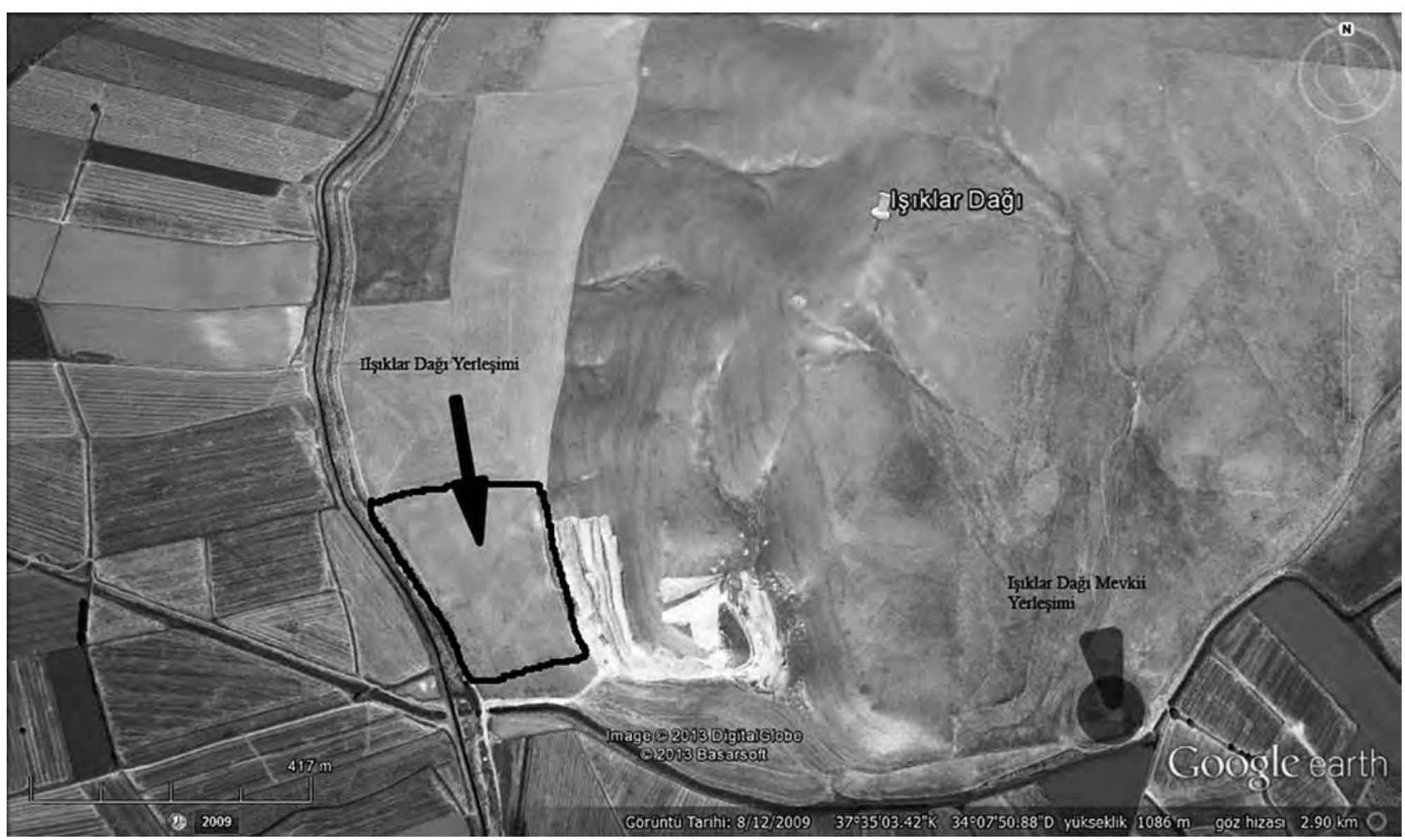

Fig. 17 : Işııklar Dağı Yerleşimi and Işıklar Dağı Mevkii Yerleşimi (Google Earth). 


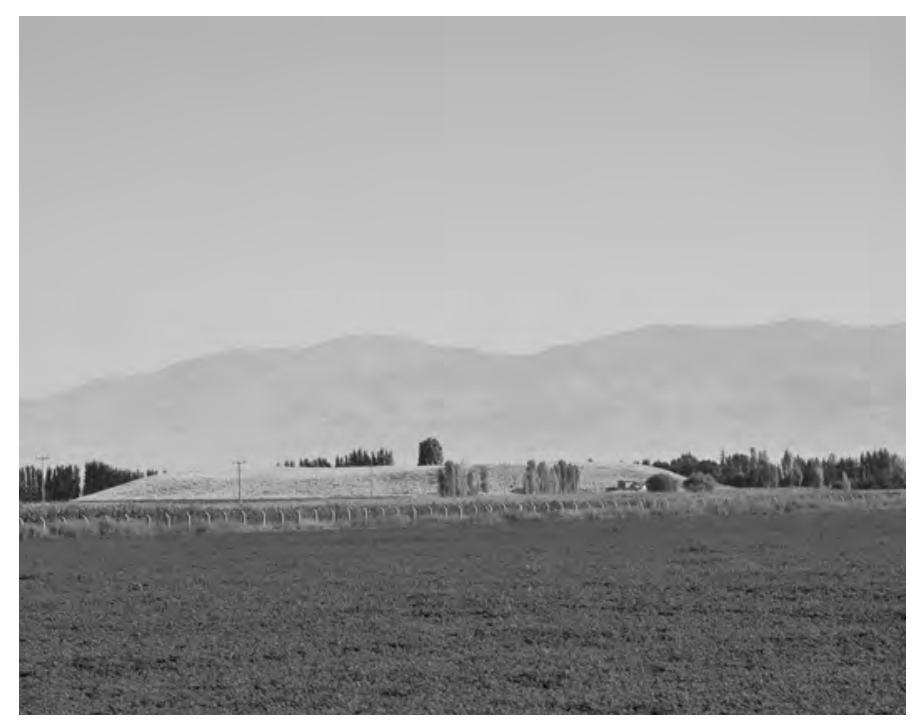

Fig. 18 : Ereğli Kara Höyük (from South).

\section{Ereğli Kara Höyük}

This mound was surveyed by $\mathrm{J}$. Mellaart ${ }^{29}$ and also S. Güneri ${ }^{30}$. In order to differentiate it from Konya Kara Höyük, this mound will be referred to as Ereğli Kara Höyük, per S. Güneri's publications. It is one of the most important ancient settlements in this region.

Ereğli Kara Höyük is situated $5.4 \mathrm{~km}$ north of the Adana-Konya highway, $1 \mathrm{~km}$ west of Aziziye (Map 1, Fig. 18). The mound is ca. 8.4 hectares wide (N-S: $274 \mathrm{~m}, \mathrm{E}-\mathrm{W}: 308 \mathrm{~m}$ ) and is one of the largest mounds of this area. In the north, Hasan Dağ is visible from the mound, which is $c a .37 \mathrm{~km}$ north of the Cilician Gates.

The settlement mound is almost circular, with steep slopes. On top, the edge has different elevations, which could be a sign that this site was once fortified. Unfortunately the mound has been heavily damaged, with many illicit excavation pits, some nearly $2 \mathrm{~m}$ deep. The southern slopes are used as a habitation area for seasonal workers and their tents.

J. Mellaart mentions tumuli near to the mound, none of which are visible today. According to local residents, the tumuli were removed to make fields, during which process bronze cauldrons, skeletons and weapons were found.

The survey here was difficult due to tall grass, which made the ground hardly visible (Fig. 19). Pot-

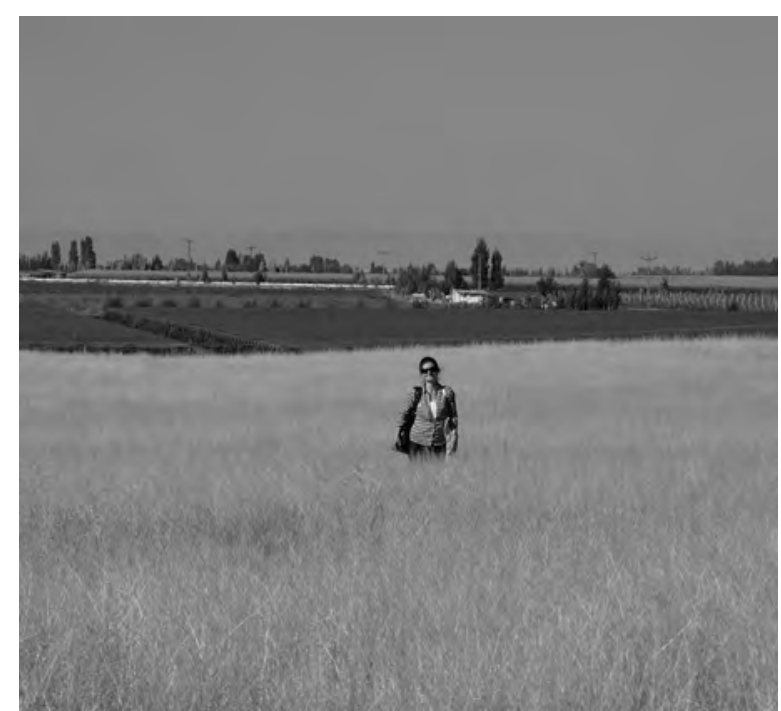

Fig. 19 : On top of Ereğli Kara Höyük: tall grass.

tery, which was mainly collected from the illicit excavation pits and from the destructed southern slope, shows a settlement occupation from Chalcolithic to Roman times (Fig. 20: 14-16). J. Mellaart and S. Güneri mentioned that mainly pottery of the $2^{\text {nd }}$ Millenium B.C. was found. This settlement appears to have been important during the Middle and Late Bronze Ages, since most of the collected pottery dates to this period. An interesting Iron Age handle was found (Fig. 20: 15), which has parallels in Porsuk Zeyve Höyük ${ }^{31}$. Among the pottery, one should also mention the presence of a Mycenaean sherd (Fig. 20: 16), which is the first Mycenaean pottery fragment found in this region. It is probably a base of a deep bowl and dates to LH III A $2^{32}$.

A piece of worked basalt stone was discovered on top of the mound. It is roughly square-shaped, and shows indications of secondary usage. There is a cavity in one corner, which suggest that this piece was used as a pivot. The piece is $c a .18 \times 15 \mathrm{~cm}$ wide. The edges and surfaces are well hammered and flattened. On the top surface a fragment of a relief is visible which is nearly roughly triangular, indicating that this piece was part of a relief slab. In comparing this small fragment with Hittite period reliefs (here Carchemish, Museum of Anatolian Civilizations), it becomes clear that the triangular elevation was likely the big toe of a foot (Fig. 2123).

29) Mellaart 1954: 180.

30) Güneri 1989-91.

31) Dupré 1983: 15 and Pl. $90 n^{\circ}$ 234. Dates to level III, Middle Iron Age.

32) Mountjoy 1986: 46 (FS 237), 87 (FS 245), 91 (FS 284). 

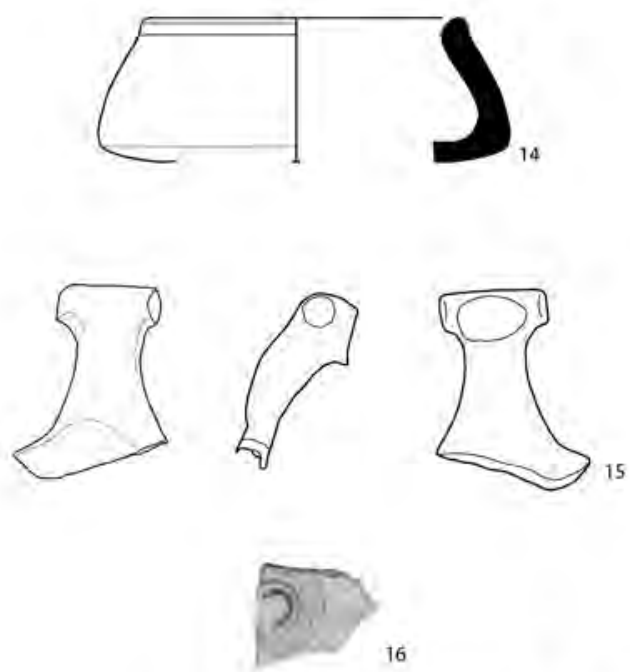

16
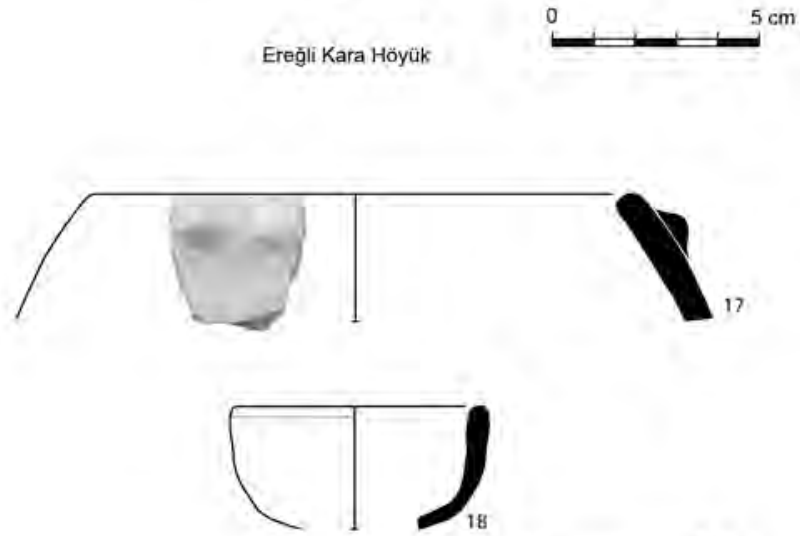

Toprak Tepe

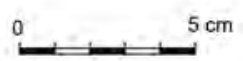

Fig. 20 : Selected pottery from Ereğli Kara Höyük and Toprak Tepe.

At the southern slope is a pile of large worked stones, including a column and a well-worked rectangular block (Fig. 24). Unfortunately the block was covered with other large stones and could not be lifted to view the reverse.

Kessler suggested that Ereğli Kara Höyük might be identified with the Hittite provincial capital Hupišna $^{33}$, an idea which is supported by the existence of $2^{\text {nd }}$ Millenium pottery and the Hittite relief slab fragment. The settlement is situated in an important strategic location in a fertile plain near the Cilician Gates, making it likely to have controlled trade in silver, as evidenced by depletion in the mountains.

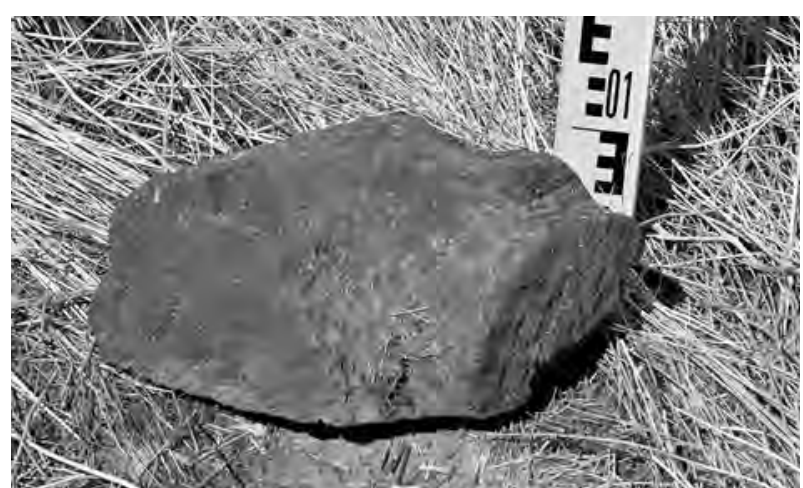

Fig. 21 : Hittite relief slab fragment from Ereğli Kara Höyük.

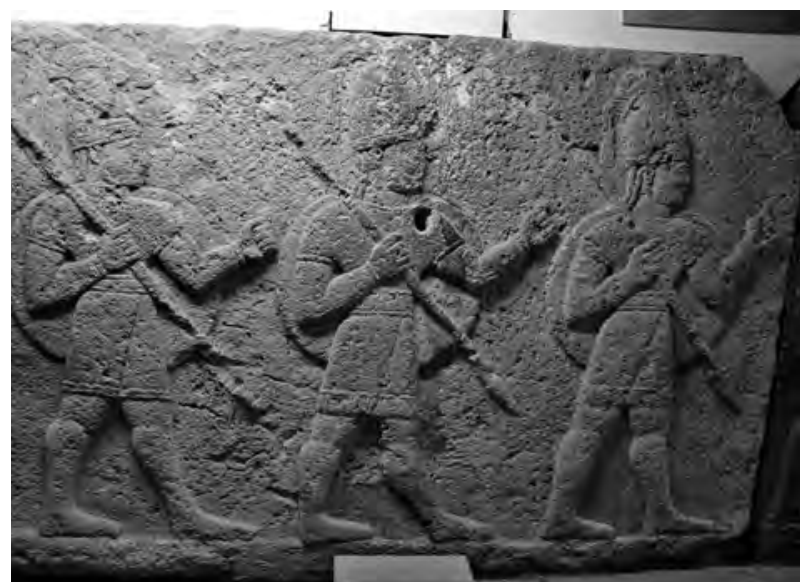

Fig. 22 : Carchemish, relief showing three soldiers, Museum of Anatolian Civilizations (photo of the author).

\section{Toprak Tepe}

Toprak Tepe is situated $c a .2 .4 \mathrm{~km}$ to the west of the Adana-Ankara highway (Map 1, Fig. 25). Toprak Tepe is a registered mound ${ }^{34}$. It is situated in fields, and also used as a field itself. The mound measures $87 \mathrm{~m}(\mathrm{~N}-\mathrm{S})$ by $83 \mathrm{~m}(\mathrm{E}-\mathrm{W})$, and is around 0.72 hectares wide. The top of the mound has been removed over the years due to farming. According to villagers, the mound was much higher and steeper at one time, though today it is a shallow mound. The pottery collected shows that the settlement was inhabited from the Late Neolithic to the Roman Period, although most of the collected pottery dates to the Chalcolithic and Early Bronze Age (Fig. 20: 18-20). Several grinding stones were also found (Fig. 26). 


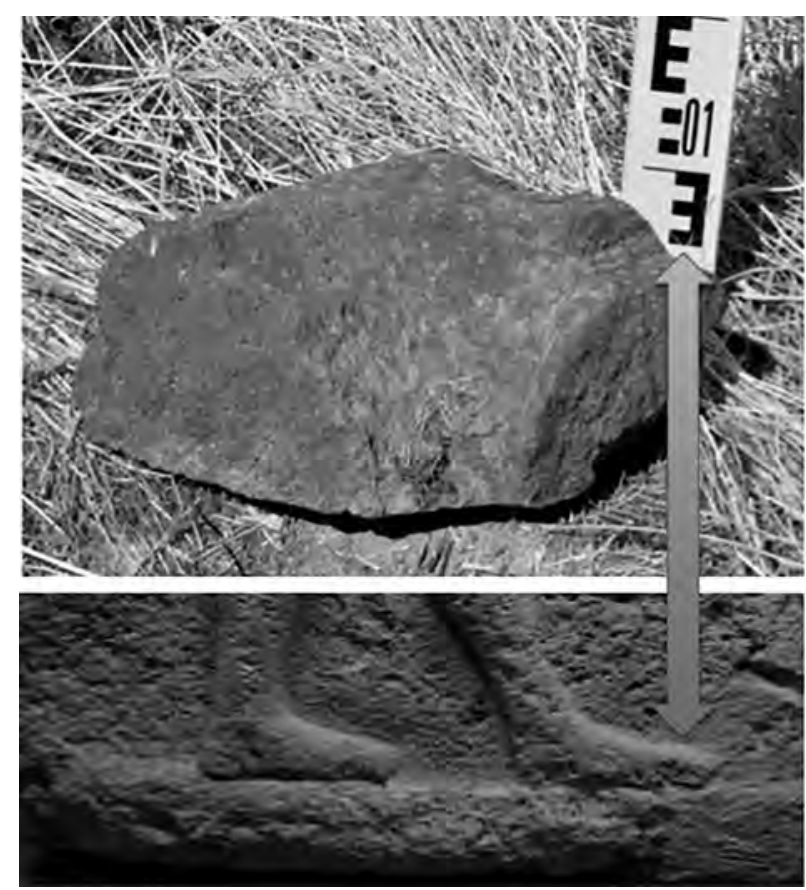

Fig. 23 : The elevation on the fragment from Ereğli Kara Höyük might be a toe of a Hittite king, god or warrior: Fragment from Ereğli Kara Höyük and feet of the soldiers on the Carchemish relief.

\section{Taştepe Obası Yerleşimi}

Taştepe Obası is situated ca. $8.2 \mathrm{~km}$ southwest of Çakmak village and $2.4 \mathrm{~km}$ north of Çayhan (Map 1). Like the settlement at Işıklar Dağg, this is also a flat settlement, which is used as a field today (Fig. 27). A villager in Çakmak mentioned that pithoi pieces and coins had been found in Taştepe Obas1, and within the village many worked stones and Roman mill pieces were observed (Fig. 28-29). They are similar to the ones known from the Museum in Ereğ $\mathrm{ii}^{35}$ and from Pompei and Morgantina ${ }^{36}$. These mill pieces indicate that this was an important production place. Among the worked stones there were also multi hollow anvil stones, which were used during the $3^{\text {rd }}$ and $2^{\text {nd }}$ Millenium B.C. to grind ores $^{37}$ (Fig. 30).

The settlement is $c a .0 .75$ hectares wide, and measures $87 \mathrm{~m}(\mathrm{~N}-\mathrm{S})$ by $87 \mathrm{~m}(\mathrm{E}-\mathrm{W})$. It is placed 8.2 $\mathrm{km}$ north of the Bolkar Mountain and the Taurus mountain range and $c a .20 \mathrm{~km}$ west of the Cilician

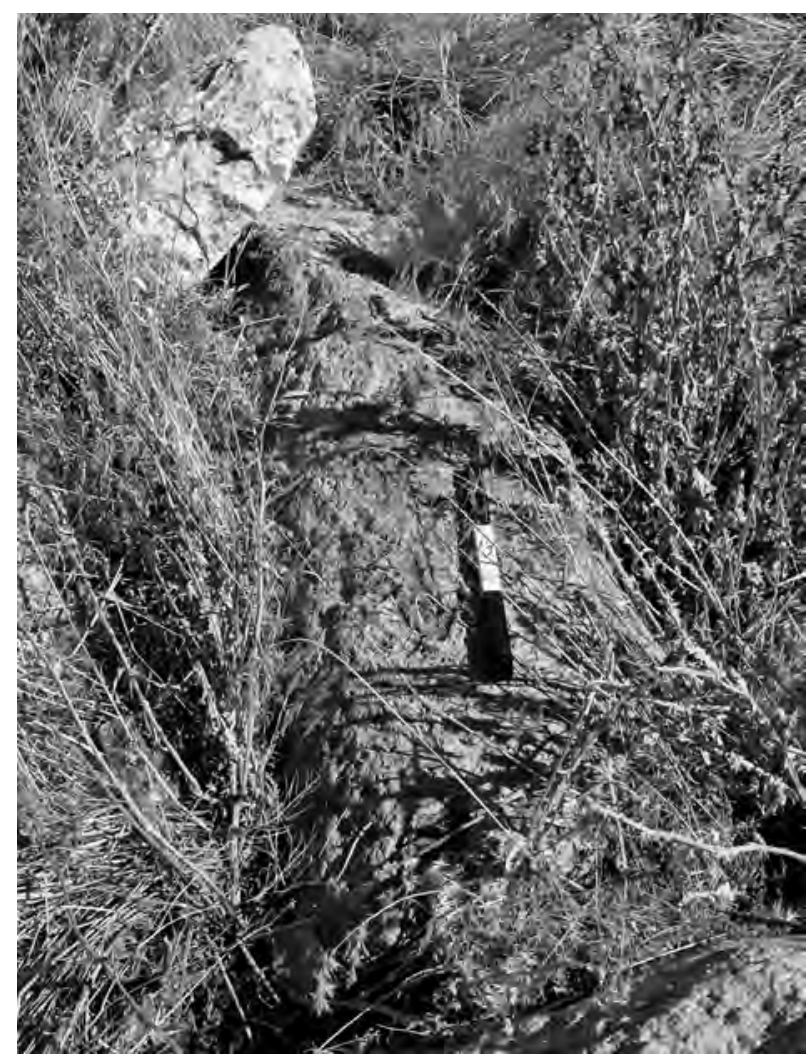

Fig. 24 : Column and other worked stones down at the south slope of Ereğli Kara Höyük.

Gates. The strategic location and the fertile land must have been an important factor in settling here. Pottery was collected from the field, but since the field is plowed the quantity was not large. Early Bronze, Late Bronze and Roman pottery was found. The evidence of the multi hollow anvil stones could indicate the presence of metal working workshop during the $3^{\text {rd }}$ and $2^{\text {nd }}$ Millenium B.C.

On the mound itself there is no evidence for architecture. In the village there are some spaces, which are covered with stones, which the villagers indicated had always been there. Whether they are parts of a construction or perhaps tombs could not be determined.

\section{Yellice Köyü Kepez Yerleşimi}

This flat settlement is situated on the slopes of the Taurus mountain at an altitude of $1332 \mathrm{~m}$ a.s.l., and was shown to us by a villager from Yellice (Map 1, Fig. 31). The ancient settlement is around

35) Unpublished.

36) White 1963: especially Fig. 6-7.

37) These kind of grinding units were discovered in Celaller (Kaptan 1988) and in Minedamı (Kaptan 1995). Both are in the Niğde region. 


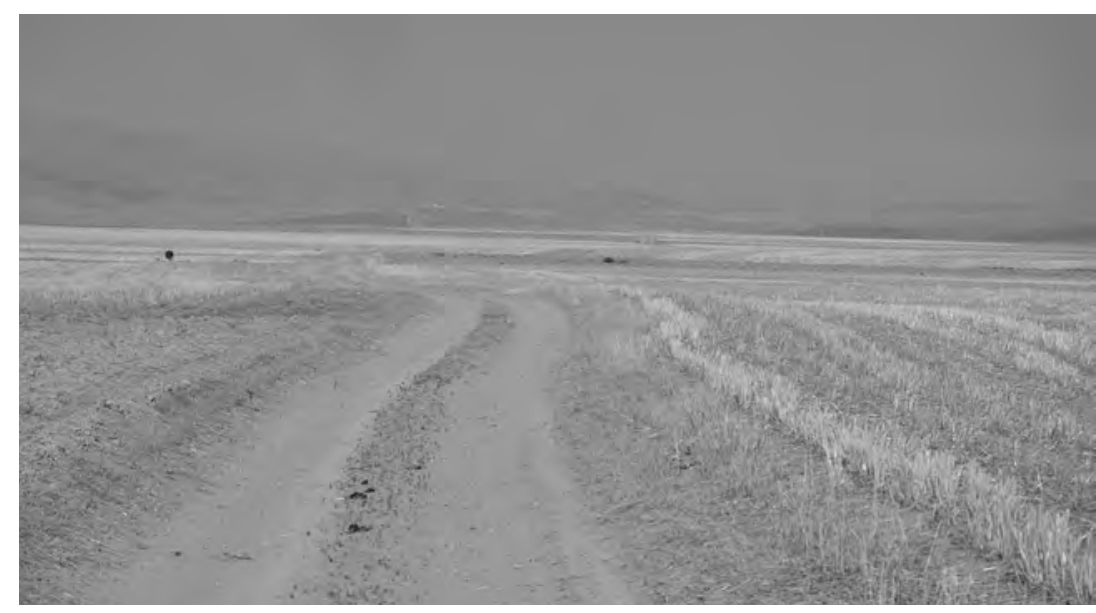

Fig. 25 : Toprak Tepe.

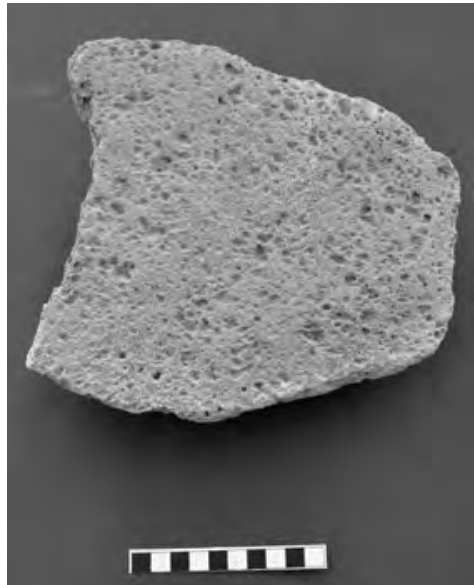

Fig. 26 : Fragment of a grinding stone.

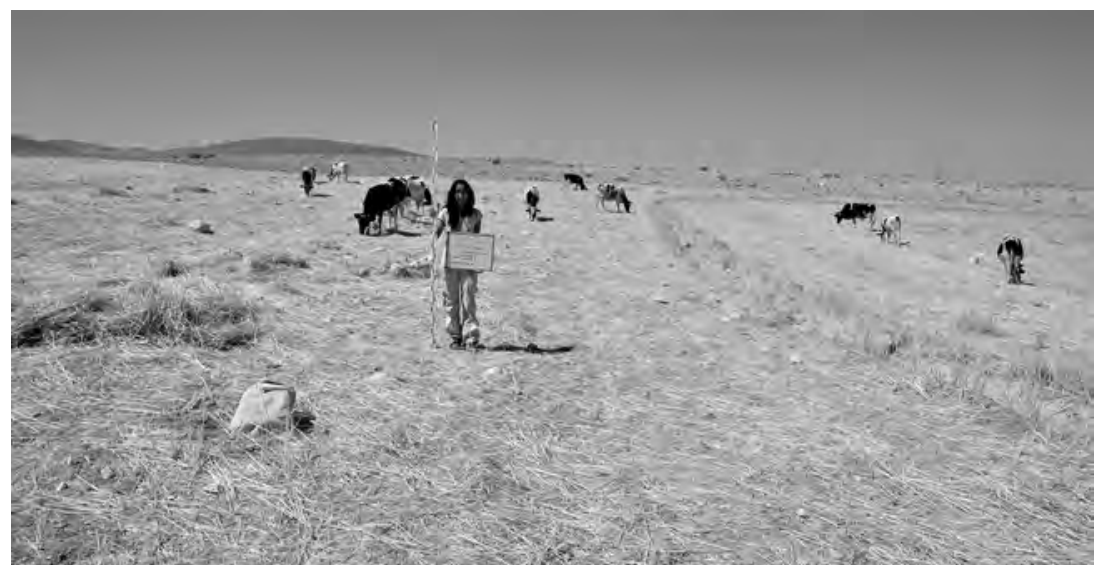

Fig. 27 : Taştepe Obası Yerleşimi (from East).

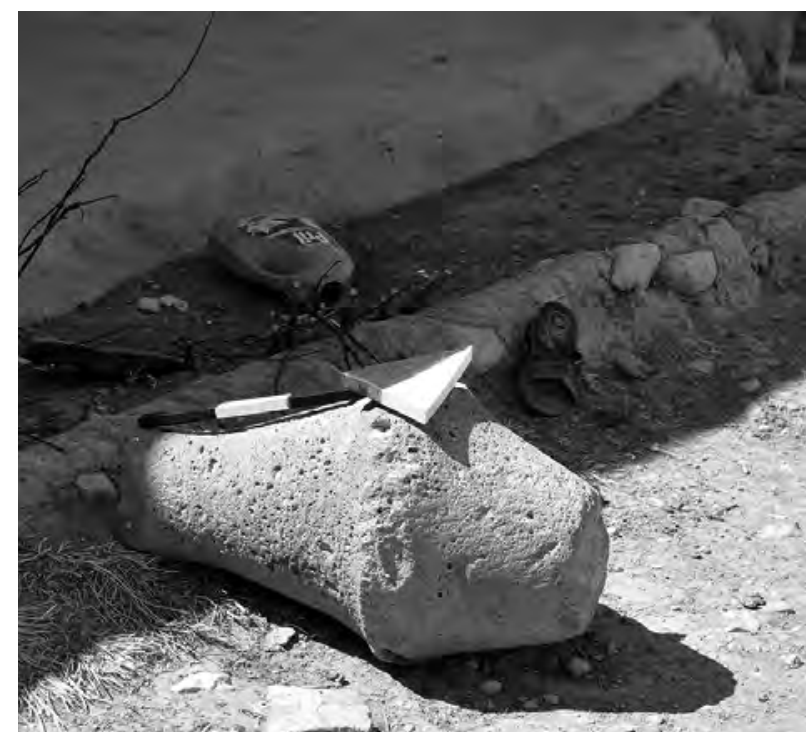

Fig. 28 : Lower half (meta) of a rotary Roman mill.

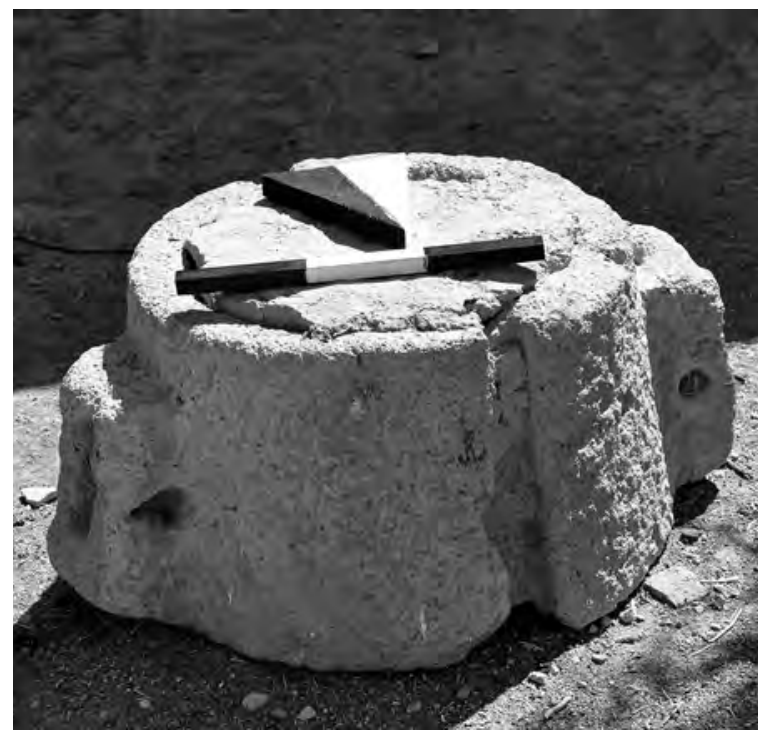

Fig. 29 : Upper half (catillus) of a rotary Roman mill. 


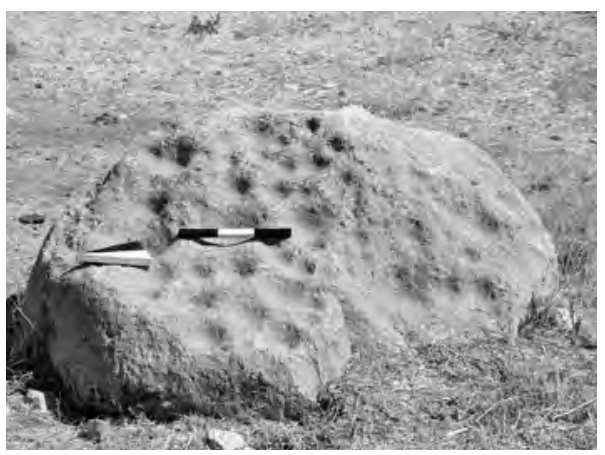

Fig. 30 : Multi hollow anvil stone.

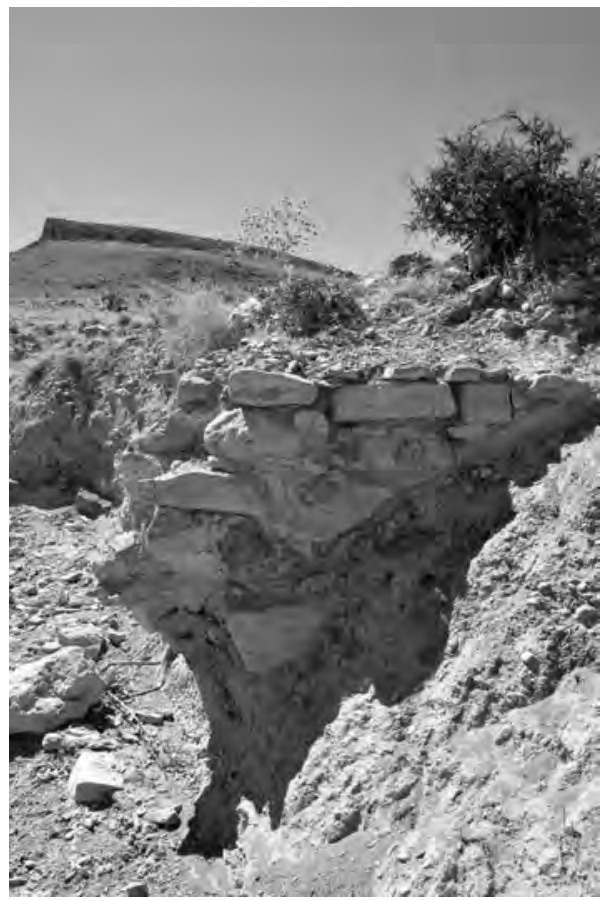

Fig. 32 : Walls (Late Antiquity) became visible after an erosion.

1 hectare wide, and measures $133 \mathrm{~m}(\mathrm{~N}-\mathrm{S})$ by $75 \mathrm{~m}$ (E-W). Pottery sherds were found in the field and a flood caused erosion, making some of the architecture visible (Fig. 32). It was difficult to measure the extent of this settlement due to the erosion and scattered nature of the pottery. Whether the scattering of the pottery was due to plowing activities or other processes could not be determined. The collected pottery dates to the Early and Late Bronze Age, Iron Age and to Roman and Byzantine periods. Fragments of Roman glass were found as well. The visible walls seem to date to the Late Antiquity, because they are made with mortar.

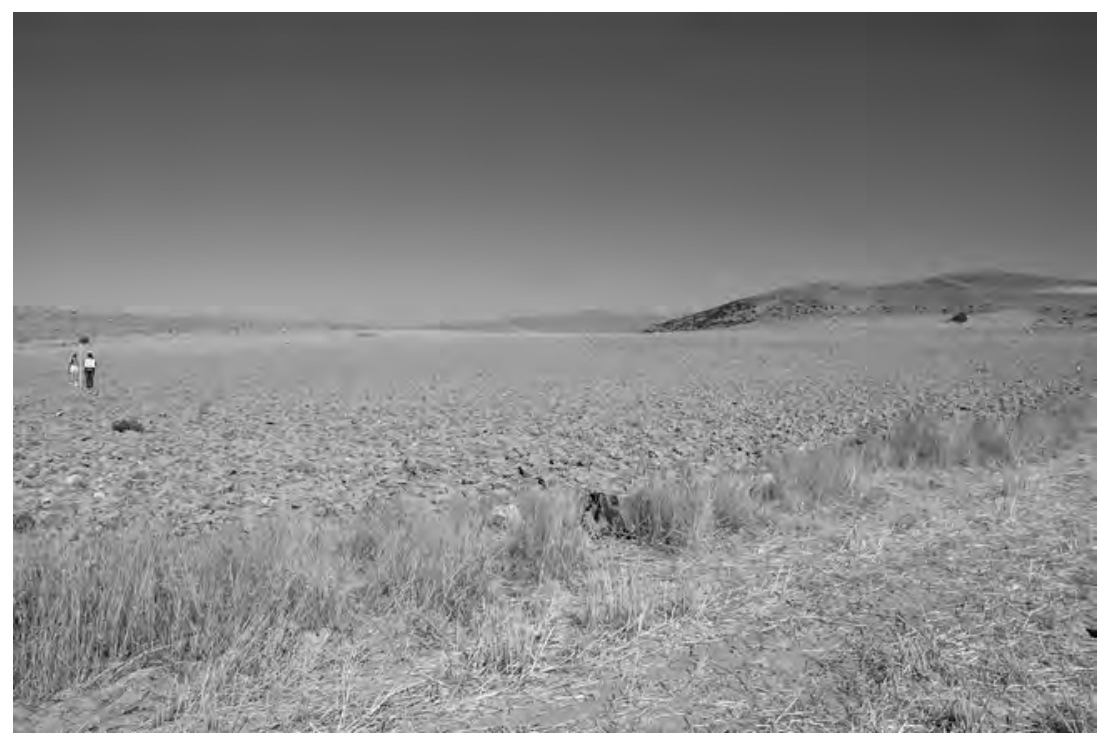

Fig. 31 : Yellice Köyü Kepez Yerleşimi (from West).

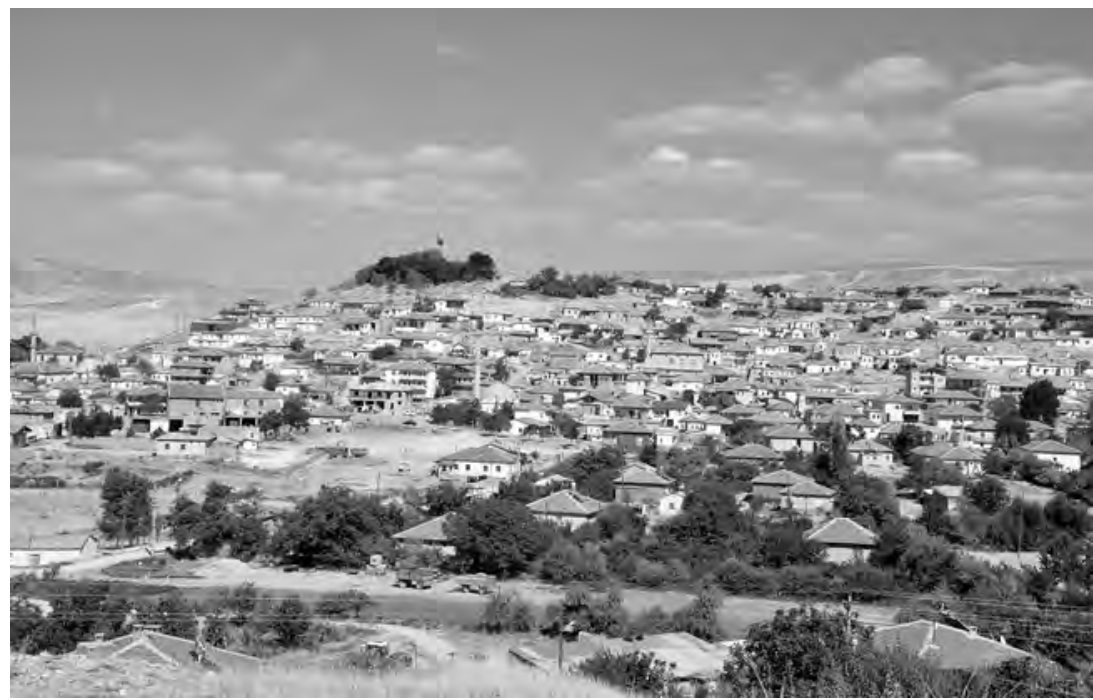

Fig. 33 : Göktepe (Çayhan).

\section{Göktepe}

Göktepe is situated at the entrance of the municipal town of Göktepe (Map. 1, Fig. 33). The ancient settlement mound is situated on top of a hill (elevation: $1262 \mathrm{~m}$ ) which overlooks the plain to the North, the Taurus mountains in the South, and the Cilician Gates in the East. Once it must have been an important strategic settlement, but today this area is used as a habitation area and forest. According to a myth of the residents, it is a Hittite settlement. Though the local residents claim that a lot of pottery and graves have been found here, on our arrival it 
was not possible to find or collect anything on the surface, because the ground had been flattened and partially paved.

\section{CONCLUSION AND FUTURE WORK}

The first field season showed that there are three types of settlements in the Ereğli region: mounds, flat settlements and hilltop settlements. At this stage the survey shows that the region was settled from the Neolithic through all of the following periods. Twelve new settlements could be identified in addition to the already known two (Ereğli Kara Höyük and Toprak Tepe). Due to its fertile land, important strategic location, proximity to the Cilician Gates and mountains with rich silver sources, it was a preferred settlement place throughout time. However, the Taurus mountains were defining a border to the South, which complicated the contact with the Mediterranean region and in some sense the region was secluded. Nonetheless, evidence for connections with the Mediterranean and also Aegean could be determined through pottery finds. The discovery of a fragment of a Hittite relief slab, and evidence of $2^{\text {nd }}$ Millennium pottery supports the theory that Ereğli Kara Höyük may be a Hittite settlement. Further investigations will show more results regarding the Hittite occupation of this region. Almost all of the surveyed sites have an Iron Age occupation as well, and the pottery shows connections with the Iron Age pottery of Porsuk-Zeyve Höyük and Tarsus Gözlü Kule.

In the second field season of KEYAR (summer 2014) we will continue the survey of Konya-Ereğli and finish this region. The result of this survey will give a complete view of that region in the Bronze and Iron Ages and also the settlement pattern during these periods. In addition the survey of the provincial town of Emirgazi will be initiated.

Ç.M.

\section{BIBLIOGRAPHY}

Aro, S. 1998: Tabal. Zur Geschichte und materiellen Kultur des zentralanatolischen Hochplateaus von 1200 bis 600 v. Chr. (unpublished Dissertation)

Bahar, H., 1998: "Hatip-Kurunta Anıtı ve Çevresi Yüzey Araştırmaları 1996", AST 15-2: 105-120.

- 2002: "Konya-Karaman İlleri Yüzey Araştırması", AST 19-2: 257-270.

- 2003: "Konya-Karaman Yüzey Araştırması", AST 20-2: 171-180.

- 2004: "Konya-Karaman Bölgesi Yüzey Araştırmaları 2002", AST 21-1: 203-216.

- 2006: "Konya-Karaman İlleri ve İlçeleri 2004 Yüzey Araştırması", AST 23-1: 95-106.

- 2007: "Konya-Karaman İlleri ve İlçeleri Yüzey Araştırması 2005", AST 24-1: 481-500.

-2008: "Konya-Karaman Yüzey Araştırmaları 2006", AST 25-1: 235-254.

- 2009: "Konya ve Karaman İlleri ve İlçeleri 2007 Y11ı Arkeolojik Yüzey Araştırması”, AST 26-1: 117-134.

- 2010: "Konya ve Karaman İlleri ve İlçelerinde Arkeolojik Yüzey Araştırması”, AST 27-3: 415-434. Wien.

Belke, K. 1984: Galatien und Lykaonien, TIB 4.

D’Alfonso, L. 2012: “Tabal, an 'out-group' definition in the First Millennium BC", in Lanfranchi, G.B., Morandi Bonacossi, D., Pappi, C. and Ponchia, S. (eds.), Leggo! Studies Presented to Prof. Frederick Mario Fales on the Occasion of His 65th Birthday, Wiesbaden: 173194.

Dupré, S., 1983: Porsuk I. La céramique de l'Age du Bronze et de l'Age du Fer, Paris.

Garstang, J. and Gurney, O.R. 1959: The Geography of the Hittite Empire, London.
Goldman, H. 1963: Excavations at Gözlü Kule, Tarsus Volume III. Text. The Iron Age, Princeton, NJ.

Güneri, S., 1989-91: "Orta Anadolu Höyükleri, Karaman-Ereğli Araştırmaları”, Türk Arkeoloji Dergisi 28-29: 97-114.

Harmanşah, Ö., 2014: "Yalburt Pınarı'nda bir Hitit Kralı, Tunç Çağı, Soğuk Sular ve Anadolu Peyzajı”, $A k$ tüel Arkeoloji Mart-Nisan 2014: 34-39.

Kaptan, E., 1988: "Türkiye Madencilik Tarihine ait Çamardı-Celaller Köyü Yöresinde Buluntular”, IV. Arkeometri Sonuçları Toplantısl: 1-16.

- 1995: "Mine Damı Araştırmaları 1993”, X. Arkeometri Sonuçları Toplantısı: 55-66.

Kessler, K., 1975: "Hupišna”, in Reallexikon der Assyriologie, Vierter Band Ha-a-a-Hystaspes: 500.

Maner, Ç. in print a: "Hethitische Funde im Museum von Konya-Ereğli und ihre Bedeutung für die hethitische Präsenz in dieser Region", Istanbuler Mitteilungen 2014. - in print b: "Searching for Hupišna. Hittite Presence in Konya-Ereğli and around", in Alparslan, M. (ed.), Hittite Places and Spaces, International Symposium, Istanbul 2013.

Mellaart, J., 1954: "Preliminary Report on a Survey of Pre-Classical Remains in Southern Turkey", AnaST 4: 175-240.

- 1963: "Early Cultures of the South Anatolian Plateau II: The Late Chalcolithic and Early Bronze Ages in the Konya Plain", AnaST 13: 199-236.

Muntjoy, P.A., 1986: Mycenaean Decorated Pottery: A Guide to Identification, Göteborg.

White, D., 1963: "A Survey of Millstones from Morgantina", AJA 67 (2): 199-206. 


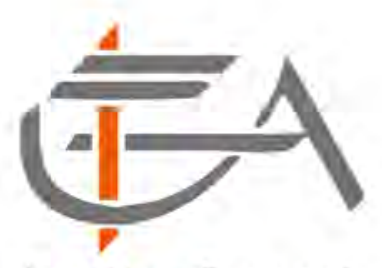

Institut Francais

d'Etudes Anatoliennes

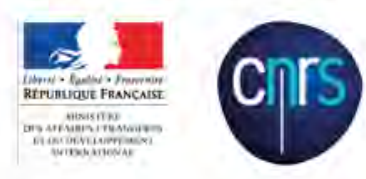

Peinture rupestre préhistorique, Sağlık Köy, près d'Alabanda, Turquie (cliché Suat Ateşlier). 